Supporting Information

\title{
In Situ X-Ray Absorption Fine Structure Analysis of PtCo, PtCu, and PtNi Alloy Electrocatalysts: The Correlation of Enhanced Oxygen Reduction Reaction Activity and Structure
}

Takahiro Kaito $^{1,2}$, Hiroyuki Tanaka ${ }^{1}$, Hisashi Mitsumoto ${ }^{1}$, Seiho Sugawara ${ }^{1}$, Kazuhiko Shinohara ${ }^{1}$, Hiroko Ariga ${ }^{3}$, Satoru Takakusagi ${ }^{3}$, and Kiyotaka Asakura ${ }^{3}$

1) Nissan Motor Co., LTD.

Natsushima-cho Yokosuka-shi Kanagawa 237-8523, Japan.

2) Department of Quantum Chemistry and Technology, Graduate School of Engineering, Hokkaido University, Kita21 Nishi10, Kita-ku, Sapporo, Hokkaido, 001-0021, Japan.

3) Institute for Catalysis, Hokkaido University, Kita21 Nishi10, Kita-ku, Sapporo, Hokkaido, 001-0021, Japan.

1. Preparation of $\mathrm{PtCo} / \mathrm{C}, \mathrm{PtCo} / \mathrm{C}-\mathrm{HT}, \mathrm{PtCu} / \mathrm{C}, \mathrm{PtCu} / \mathrm{C}-\mathrm{HT}$, and $\mathrm{PtNi} / \mathrm{C}$ electrocatalysts

2. Electrochemical measurements

3. XAFS analyses

4. Transmission electron microscopy

5. X-ray diffraction

6. ORR activities of $\mathrm{Pt} / \mathrm{C}, \mathrm{PtCo} / \mathrm{C}, \mathrm{PtCo} / \mathrm{C}-\mathrm{HTs}, \mathrm{PtCu} / \mathrm{C}, \mathrm{PtCu} / \mathrm{C}-\mathrm{HT}$, and $\mathrm{PtNi} / \mathrm{C}$ electrocatalysts

7. XANES analyses of $\mathrm{PtCo} / \mathrm{C}, \mathrm{PtCo} / \mathrm{C}-\mathrm{HTs}, \mathrm{PtCu} / \mathrm{C}, \mathrm{PtCu} / \mathrm{C}-\mathrm{HT}$, and $\mathrm{PtNi} / \mathrm{C}$ electrocatalysts

8. XAFS analyses of reference foils and a $\mathrm{Pt} / \mathrm{C}$ base electrocatalyst

9. Detailed discussions of the PtCo/C electrocatalyst based on XAFS and XRD data

10. $\mathrm{Pt}_{3} \mathrm{Co}$ intermetallic compound structure

11. Model structures for PtNi, PtCo, and PtCu electrocatalysts

12. Numbers of edge atoms, particle sizes, and coordination numbers of electrocatalyst particles

13. Correlation between ORR activity and bond length based on literature data

14. Atomic ratio of prepared electrocatalyst before the electrochemical testing

1. Preparation of $\mathrm{PtCo} / \mathrm{C}, \mathrm{PtCo} / \mathrm{C}-\mathrm{HT}, \mathrm{PtCu} / \mathrm{C}, \mathrm{PtCu} / \mathrm{C}-\mathrm{HT}$, and $\mathrm{PtNi} / \mathrm{C}$ electrocatalysts

Samples with two different $\mathrm{Pt} / \mathrm{Co}$ ratios were prepared, employing several treatment temperatures, as follows. A $22.3 \mathrm{~g}$ quantity of a $2.4 \mathrm{wt} \%$ aqueous $\mathrm{CoCl}_{2}$ solution was poured into a beaker containing $1 \mathrm{~L}$ of ultrapure water, with magnetic stirring, followed by the addition of $0.6 \mathrm{~g}$ of a $40.6 \mathrm{wt} \%$ aqueous $\mathrm{H}_{2} \mathrm{PtCl}_{4}$ solution. After stirring for $5 \mathrm{~min}, 100 \mathrm{~mL}$ of reducing agent (a mixture of $0.4 \mathrm{~g} \mathrm{NaBH}_{4}$ and $1.2 \mathrm{~g}$ trisodium citrate $\left(\mathrm{C}_{6} \mathrm{H}_{5} \mathrm{Na}_{3} \mathrm{O}_{7} \cdot 2 \mathrm{H}_{2} \mathrm{O}\right)$ dissolved in ultrapure 
water) was slowly added to the beaker. Following a further 30 min stirring, the Pt and Co ions had been reduced to form PtCo alloy particles, and $0.2 \mathrm{~g}$ of Ketjenblack (previously dispersed in 100 $\mathrm{mL}$ ultrapure water) was slowly transferred into the beaker. After $72 \mathrm{~h}$ of continuous stirring at room temperature, the resulting $\mathrm{PtCo} / \mathrm{C}$ was removed by filtration and dried for more than $4 \mathrm{~h}$ at 60 ${ }^{\circ} \mathrm{C}$. As a final step, the dry $\mathrm{PtCo} / \mathrm{C}$ on the filter was scraped off to obtain the carbon-supported electrocatalyst powder. This product was subsequently heated under argon at various temperatures (either 600,700 , or $800{ }^{\circ} \mathrm{C}$ ). The 600 and $700{ }^{\circ} \mathrm{C}$ samples were heated for $2 \mathrm{~h}$, while the $800{ }^{\circ} \mathrm{C}$ specimen was heated for only $1 \mathrm{~h}$ to avoid coalescence. The samples are denoted in the form of $\mathrm{PtCo} / \mathrm{C}-\mathrm{HT}-600$, where the last numeral indicates the heat treatment temperature. This process was changed for the preparation of $\mathrm{PtCo} / \mathrm{C}$ with a higher Co concentration by doubling the amount of the aqueous $\mathrm{CoCl}_{2}$ solution. The sample thus obtained is denoted as $\mathrm{PtCo} / \mathrm{C}-\mathrm{HT}-600 \mathrm{~h}$, where the final " $h$ " indicates the higher Co concentration.

For the preparation of the $\mathrm{PtCu} / \mathrm{C}$ electrocatalyst, $\mathrm{CuCl}_{2}$ was used in place of $\mathrm{CoCl}_{2}$, but otherwise the preparation process was unchanged except that hydrogen was used rather than argon during heat treatment.

The preparation process for the $\mathrm{PtNi} / \mathrm{C}$ electrocatalyst was slightly different from that of the above two electrocatalysts. In this procedure, $1 \mathrm{~L}$ of ultrapure water was transferred into a beaker and $22.3 \mathrm{~g}$ of a $2.4 \mathrm{wt} \%$ aqueous $\mathrm{NiCl}_{2}$ solution was added with stirring. Subsequently, $100 \mathrm{~mL}$ of the reducing agent (a mixture of $0.4 \mathrm{~g} \mathrm{NaBH}_{4}$ and $1.2 \mathrm{~g} \mathrm{C}_{6} \mathrm{H}_{5} \mathrm{Na}_{3} \mathrm{O}_{7} \cdot 2 \mathrm{H}_{2} \mathrm{O}$ dissolved in ultrapure water) was poured into the beaker, and the mixture was stirred for $30 \mathrm{~min}$ to allow for the reduction of the $\mathrm{Ni}$ ions. At this point, $0.6 \mathrm{~g}$ of a $15.3 \mathrm{wt} \%$ aqueous $\mathrm{H}_{2} \mathrm{PtCl}_{4}$ solution was added, followed by stirring for an additional $30 \mathrm{~min}$ and the subsequent addition of a dispersion of the Ketjenblack carbon support.

The atomic ratio of these electrocatalysts as prepared before the electrochemical testing is shown in Table S1. 


\section{Electrochemical measurements}

To determine their ORR activities, the $\mathrm{Pt} / \mathrm{C}, \mathrm{PtCo} / \mathrm{C}, \mathrm{PtCo} / \mathrm{C}-\mathrm{HTs}, \mathrm{PtCu} / \mathrm{C}, \mathrm{PtCu} / \mathrm{C}-\mathrm{HT}$, and $\mathrm{PtNi} / \mathrm{C}$ were each dispersed in a solvent mixture consisting of ultrapure water and Nafion ionomer (DuPont) by ultrasonication for 30 min to produce electrochemical inks. Each of these inks was then deposited on the pre-cleaned glassy carbon substrate of a rotating disk electrode (RDE) in amounts so as to obtain Pt loadings of $8.3 \mu \mathrm{g}-\mathrm{Pt} / \mathrm{cm}^{2}$ for $\mathrm{PtCu} / \mathrm{C}-\mathrm{HT}$ samples, $10 \mu \mathrm{g}-\mathrm{Pt} / \mathrm{cm}^{2}$ for $\mathrm{PtCo} / \mathrm{C}$ and $\mathrm{PtCo} / \mathrm{C}-\mathrm{HT}$ samples, and $17 \mu \mathrm{g}-\mathrm{Pt} / \mathrm{cm}^{2}$ for $\mathrm{Pt} / \mathrm{C}, \mathrm{PtCu} / \mathrm{C}$, and $\mathrm{PtNi} / \mathrm{C}$ samples. Subsequently, each RDE was dried at $60^{\circ} \mathrm{C}$.

Electrochemical analysis was conducted with an RDE measurement apparatus (HZ-5000, Hokuto Denko Corp.). During electrochemical experiments, a reversible hydrogen electrode (RHE) and a Pt mesh were used as the reference electrode and the counter electrode, respectively. Cyclic voltammograms (CVs) were obtained in a deaerated $0.1 \mathrm{M} \mathrm{HClO}_{4}$ solution at a sweep rate of 50 $\mathrm{mVs}^{-1}$, while polarization curves were recorded in an $\mathrm{O}_{2}$ saturated $0.1 \mathrm{M} \mathrm{HClO}_{4}$ solution at a sweep rate of $10 \mathrm{mVs}^{-1}$. 


\section{XAFS analyses}

The analysis of XAFS data was performed using the REX2000 software program. The XAFS oscillation values, $\chi(k)$, were extracted from the measurement data, $\mu(E)$, by subtracting the smoothly varying component, $\mu_{\mathrm{s}}(E)$, using estimations via a spline smoothing method. ${ }^{1}$ This was followed by the normalization of the edge height values, $\mu_{0}(E)$, the energy dependence of which was estimated using the McMaster parameters. ${ }^{2}$

$$
\chi(\boldsymbol{k})=\frac{\mu(E)-\mu_{s}(E)}{\mu_{0}(E)}
$$

Here, $k$ is the wavenumber of the photoelectron, which is related to the photon energy, $E$, and the threshold energy, $E_{0}$, as in the following equation; $k=\frac{1}{\hbar} \sqrt{2 m\left(E-E_{0}\right)}$, where $m$ is the mass of the electron.

The $k^{3} \chi(k)$ values underwent Fourier transform to $r$ space, after which the peak in the Fourier transform was filtered and then underwent inverse Fourier transform back to $k$ space. The Fourierfiltered data were subsequently analyzed with a curve-fitting technique using the following theoretical XAFS equations.

$$
\begin{gathered}
k^{3} \chi(k)=\sum_{j} \frac{k_{j}^{2} S_{j} N_{j} F_{j}\left(k_{j}\right) \exp \left(-2 k_{j}^{2} \sigma_{j}^{2}\right)}{r_{j}^{2}} \sin \left(2 k_{j} r_{j}+\phi_{j}(k)\right) \\
\boldsymbol{k}_{\boldsymbol{j}}=\left(\boldsymbol{k}^{2}-\frac{2 m \Delta E_{0 j}}{\hbar^{2}}\right)^{\frac{1}{2}}
\end{gathered}
$$

Here, $N_{j}, r_{j}, \Delta E_{0 j}$, and $\sigma_{j}$ are the coordination number, the bond length, the difference between the and experimental threshold energies, and the Debye-Waller factor for the $j^{\text {th }}$ coordination shell, respectively. These were used as fitting parameters. The terms $\phi_{j}(k)$ and $F_{j}(k)$ are the phase shift and amplitude function for the $j^{\text {th }}$ coordination shell, respectively, both of which were derived from FEFF8 calculations. ${ }^{3}$ The amplitude reduction factor, $S_{j}$, arises from many-body effects and from inelastic losses in the scattering process. Since many-body effects and inelastic losses vary with $k$ in opposite directions, $S_{j}$ can be regarded as a constant function of $k{ }^{4}$

In the curve-fitting analyses, $S_{j}$ and $\Delta E_{0 j}$ were fixed at the values obtained from the Pt, Co, and $\mathrm{Cu}$ foils for the metallic PtM species. The quality of the fit was evaluated by the $R$-factor,

$$
R=\frac{\sum\left(k^{3} \chi_{o b s}(k)-k^{3} \chi_{c a l c}(k)\right)^{2}}{\sum\left(k^{3} \chi_{o b s}(k)\right)^{2}}
$$

where $\chi_{\text {obs }}(k)$ and $\chi_{\text {calc }}(k)$ are the observed and calculated $\chi(k)$, respectively. 


\section{Transmission electron microscopy}

Figures $\mathrm{S} 1$ and $\mathrm{S} 2$ show TEM images and the particle size distributions of the $\mathrm{PtCu} / \mathrm{C}, \mathrm{PtCo} / \mathrm{C}$ HT-600, PtCo/C-HT-700, PtCo/C-HT-800, and PtCu/C-HT-600 materials. Average diameter of $\mathrm{PtCo} / \mathrm{C}-\mathrm{HT}-800$ was smaller than that of PtCo/C-HT-600, PtCo/C-HT-700 in spite of its higher heat treatment temperature. This is because the heat treatment time of 800 was 1 hour shorter than that of both PtCo/C-HT-600, PtCo/C-HT-700 and the aggregation was inhibited.

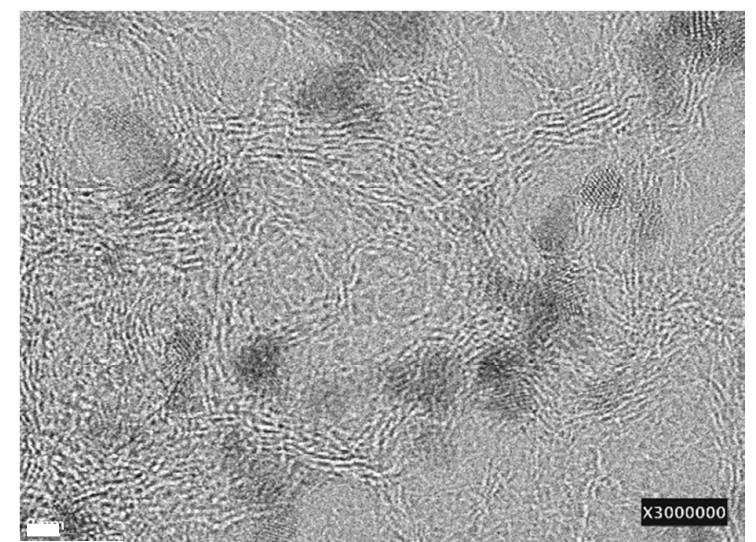

$2 \mathrm{~nm}$

(a) $\mathrm{PtCu} / \mathrm{C}$

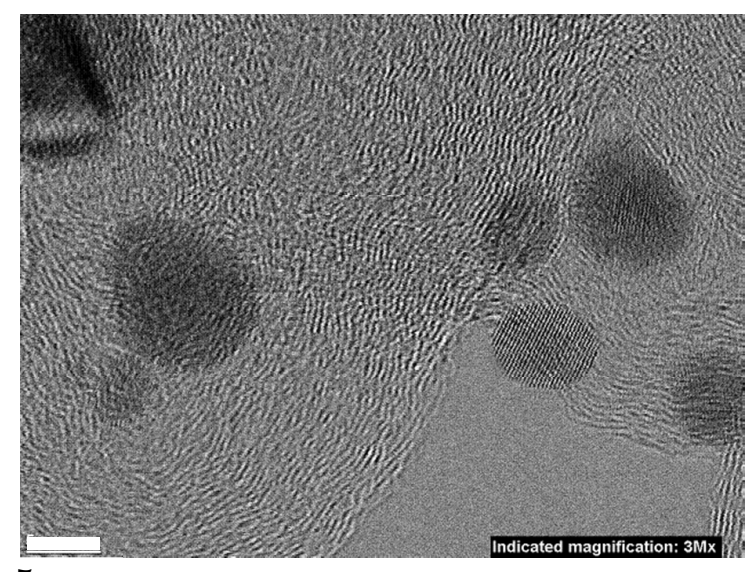

$5 \mathrm{~nm}$

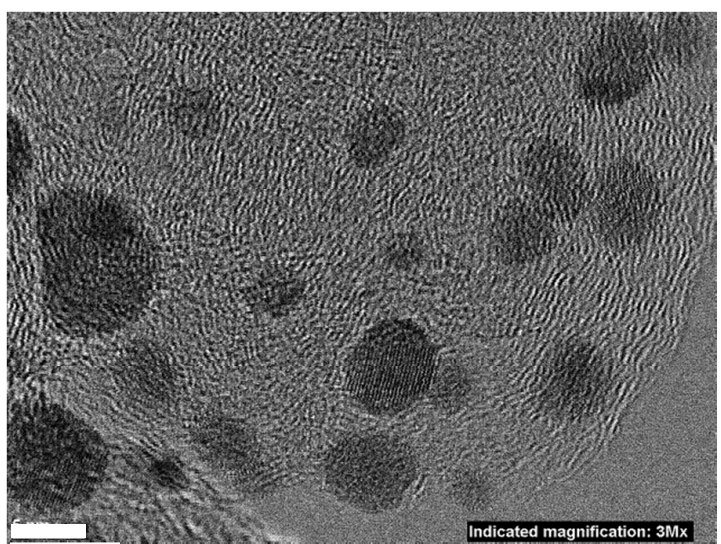

$5 \mathrm{~nm}$

(b) PtCo/C-HT-600

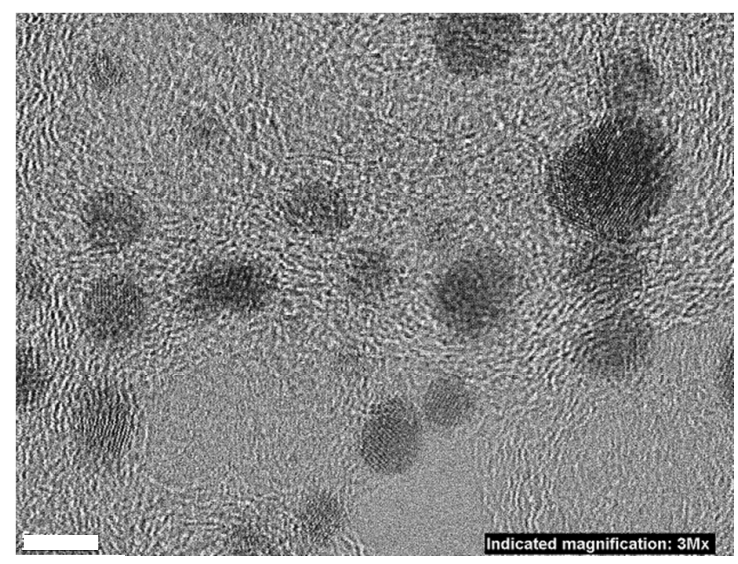

$5 \mathrm{~nm}$

(c) $\mathrm{PtCo} / \mathrm{C}-\mathrm{HT}-700$

(d) $\mathrm{PtCo} / \mathrm{C}-\mathrm{HT}-800$ 


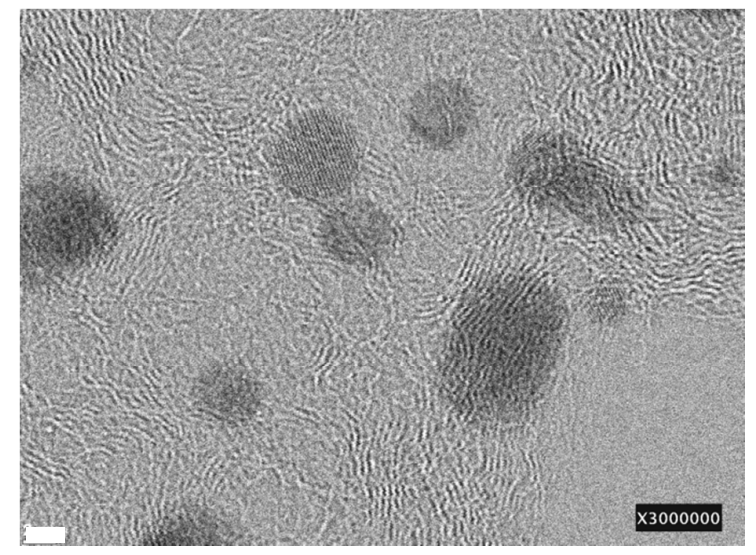

$2 \mathrm{~nm}$

(e) PtCu/C-HT-600

Figure S1. TEM images of (a) $\mathrm{PtCu} / \mathrm{C}$ without heat treatment and the heat-treated (b) PtCo/C-HT600, (c) PtCo/C-HT-700, (d) PtCo/C-HT-800, and (e) PtCu/C-HT-600. 


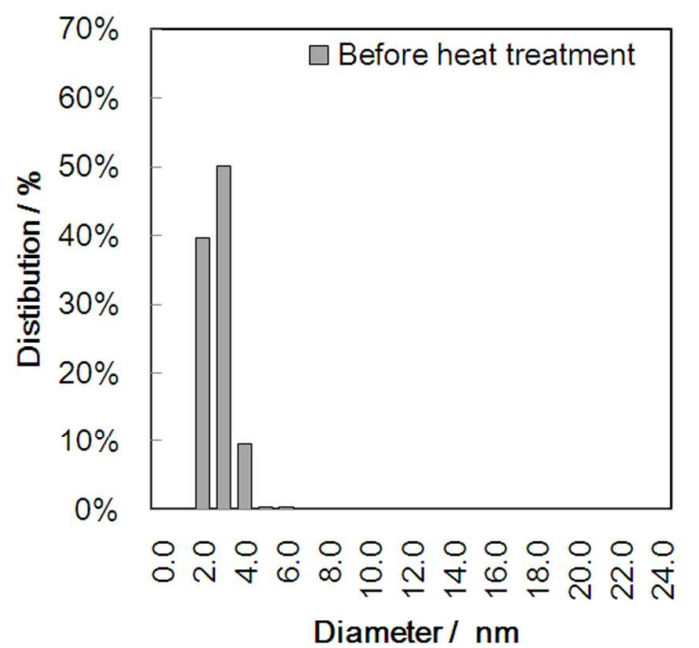

(a) $\mathrm{PtCu} / \mathrm{C}$

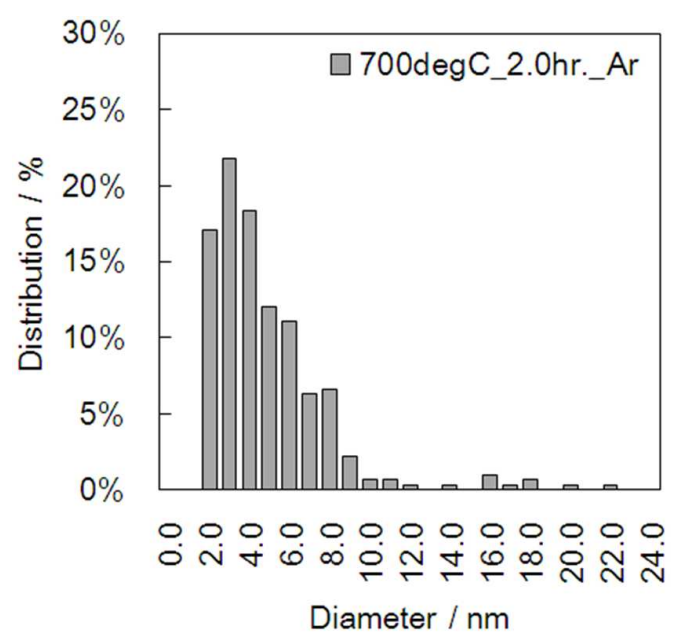

(c) $\mathrm{PtCo} / \mathrm{C}-\mathrm{HT}-700$

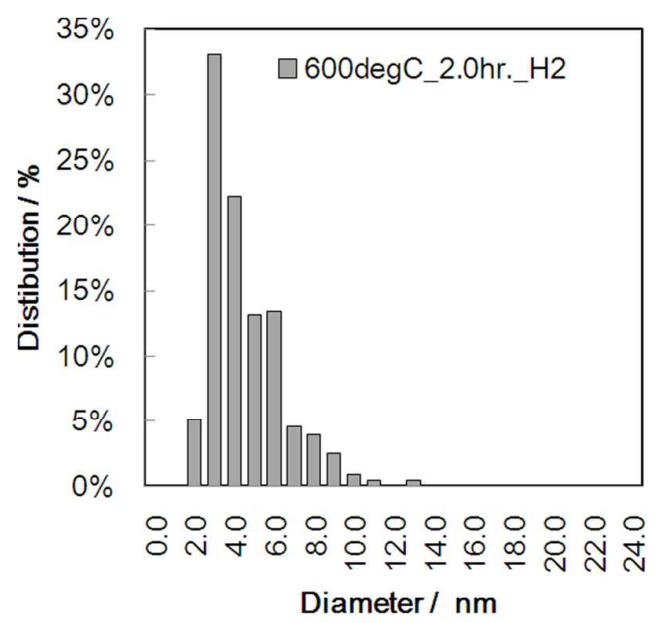

(e) $\mathrm{PtCu} / \mathrm{C}-\mathrm{HT}-600$

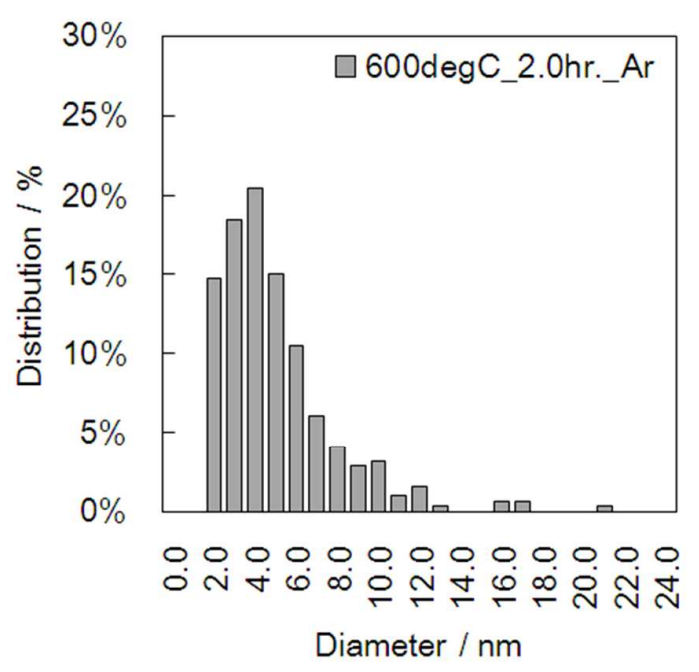

(b) $\mathrm{PtCo} / \mathrm{C}-\mathrm{HT}-600$

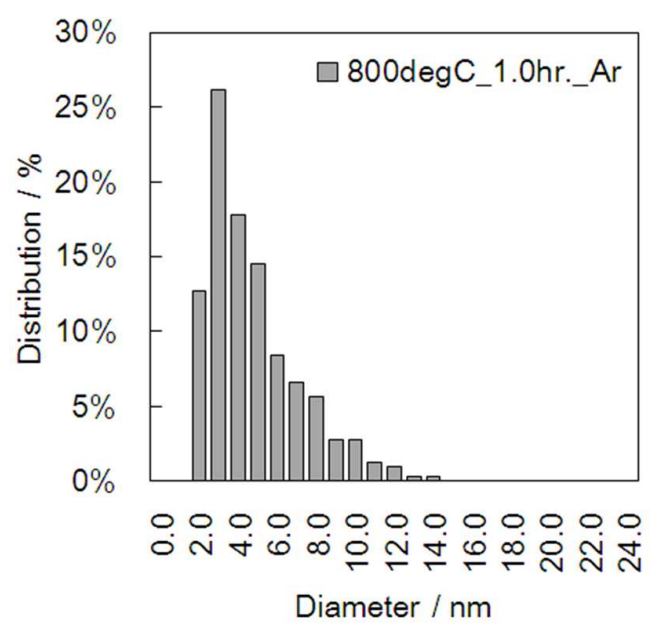

(d) $\mathrm{PtCo} / \mathrm{C}-\mathrm{HT}-800$

Figure S2. Particle diameter distributions of (a) $\mathrm{PtCu} / \mathrm{C}$ without heat treatment and the heattreated (b) PtCo/C-HT-600, (c) PtCo/C-HT-700, (d) PtCo/C-HT-800, and (e) PtCu/C-HT-600. 


\section{X-ray diffraction}

Figure S3 presented the XRD diffraction patterns obtained from $\mathrm{Pt} / \mathrm{C}, \mathrm{PtCo} / \mathrm{C}, \mathrm{PtCo} / \mathrm{C}-\mathrm{HT}-600$, $\mathrm{PtCo} / \mathrm{C}-\mathrm{HT}-700$, and PtCo/C-HT-800 and Table S1 summarizes the lattice constants of these electrocatalysts. Prior to heat treatment, broad peaks are observed and the $43.6^{\circ}$ peak corresponding to Co particles is ambiguous. Following heat treatment, the peaks are sharper as the result of increased crystallization and indicate a typical Pt face-centered cubic (fcc) structure. In addition, the absence of isolated Co particles is evident because there is no peak at $43.6^{\circ}$. The peaks generated by the untreated $\mathrm{PtCo} / \mathrm{C}$ are shifted to higher $2 \theta$ angles compared to those of the $\mathrm{Pt} / \mathrm{C}$, while the $\mathrm{PtCo} / \mathrm{C}-\mathrm{HTs}$ peaks are shifted to even higher values, indicating contraction of the lattice constants upon both alloying and heat treatment, as shown in Table S1. Compared to the theoretical $\mathrm{Pt}_{3} \mathrm{Co}$ intermetallic diffraction pattern, the peaks at approximately $33^{\circ}$ and $23^{\circ}$ are just barely observed in the $\mathrm{PtCo} / \mathrm{C}$-HT samples.

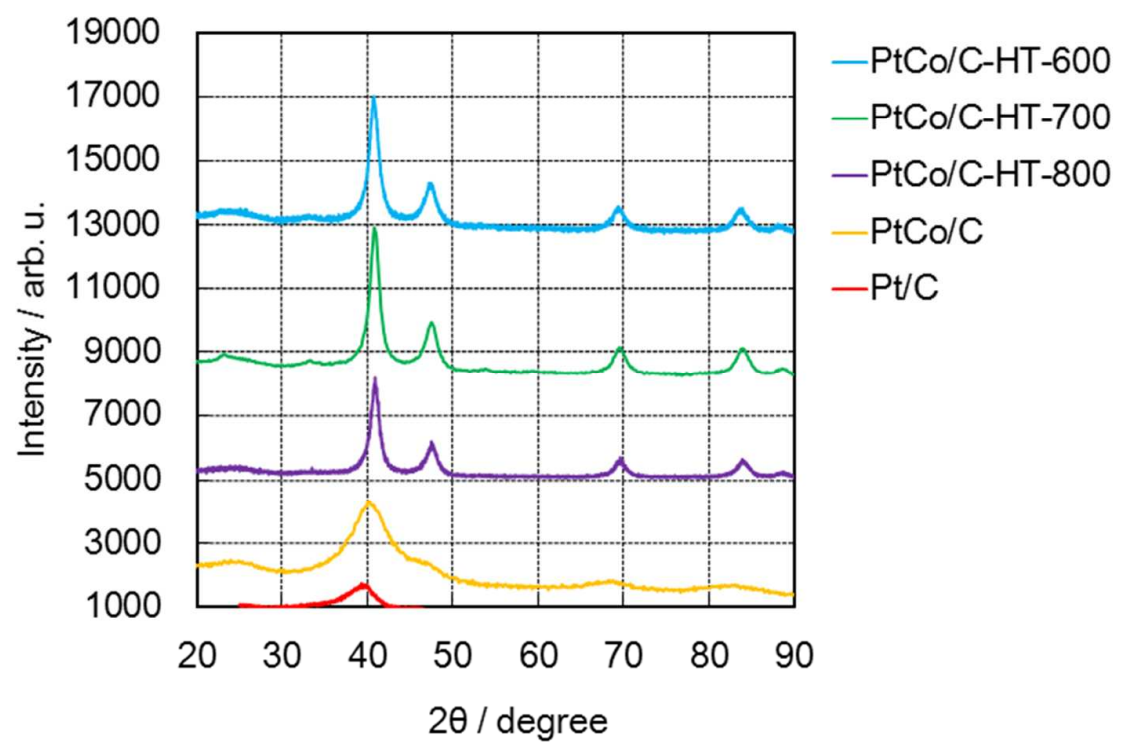

Figure S3. X-ray diffraction patterns obtained from $\mathrm{PtCo} / \mathrm{C}$ and heat-treated $\mathrm{PtCo} / \mathrm{C}-\mathrm{HT}-600$, $\mathrm{PtCo} / \mathrm{C}-\mathrm{HT}-700$, and PtCo/C-HT-800.

Table S1. Lattice constants of the PtCo/C, PtCo/C-HT-600, PtCo/C-HT-700, and PtCo/C-HT-800 samples shown in Fig. S3.

\begin{tabular}{cc}
\hline \hline & Lattice constant $/ \mathrm{nm}$ \\
\hline $\mathrm{PtCo} / \mathrm{C}$ & 0.388 \\
\hline $\mathrm{PtCo} / \mathrm{C}-\mathrm{HT}-600$ & 0.383 \\
\hline $\mathrm{PtCo} / \mathrm{C}-\mathrm{HT}-700$ & 0.382 \\
\hline $\mathrm{PtCo} / \mathrm{C}-\mathrm{HT}-800$ & 0.382 \\
\hline \hline
\end{tabular}


6. ORR activities of $\mathrm{Pt} / \mathrm{C}, \mathrm{PtCo} / \mathrm{C}, \mathrm{PtCo} / \mathrm{C}-\mathrm{HT}, \mathrm{PtCu} / \mathrm{C}, \mathrm{PtCu} / \mathrm{C}-\mathrm{HT}$, and $\mathrm{PtNi} / \mathrm{C}$ electrocatalysts

Figure $\mathrm{S} 4$ presents the $\mathrm{CVs}$ generated by the $\mathrm{Pt} / \mathrm{C}, \mathrm{PtCo} / \mathrm{C}, \mathrm{PtCo} / \mathrm{C}-\mathrm{HT}, \mathrm{PtCu} / \mathrm{C}, \mathrm{PtCu} / \mathrm{C}-\mathrm{HT}$, and $\mathrm{PtNi} / \mathrm{C}$. The experimental $\mathrm{CV}$ data were normalized by the electrochemical effective areas (ECAs). The ECAs were determined by first calculating the $S_{\mathrm{Pt}}$ values through dividing the hydrogen adsorption charges by the adsorption density of $210 \mu \mathrm{C} / \mathrm{cm}^{2}{ }^{5}$. The ECA of each sample was then calculated based on the $S_{\mathrm{Pt}}$ value and the Pt loading on the RDE disc. As shown in Fig. $\mathrm{S} 4(\mathrm{a})$, the $\mathrm{CVs}$ of the $\mathrm{PtCo} / \mathrm{C}$ and $\mathrm{PtCo} / \mathrm{C}-\mathrm{HT}$ samples were similar. However, Fig. S4(b) demonstrates that the normalized currents of the $\mathrm{PtCu} / \mathrm{C}-\mathrm{HT}$ and $\mathrm{PtNi} / \mathrm{C}$ were somewhat larger than those generated by the other samples. This occurs because the $S_{\mathrm{Pt}}$ values of the $\mathrm{PtCu} / \mathrm{C}-\mathrm{HT}$ and $\mathrm{PtNi} / \mathrm{C}$ samples are smaller than those of the other specimens. The smaller $S_{\mathrm{Pt}}$ of the $\mathrm{PtNi} / \mathrm{C}$ is believed to have resulted from the larger average particle diameter of this material as well as the effect of the inner surface of the hollow structure. However, the reason for the lower $S_{\mathrm{Pt}}$ of the $\mathrm{PtCu} / \mathrm{C}$-HT remains unclear. On the whole, these $\mathrm{CVs}$ indicate typical responses of Pt alloy electrocatalysts, comparable to that of $\mathrm{Pt} / \mathrm{C}$.

Polarization curves for the ORR activities of the electrocatalysts were obtained in a $0.1 \mathrm{M}$ $\mathrm{HClO}_{4}$ solution, purged and saturated with $99.99 \%$ oxygen, at various rotational speeds $(400,800$, $1200,1600$, and $2000 \mathrm{rpm})$. An IR-drop correction was applied to the potential values obtained from the measurement system to take into account the resistance between the working and reference electrodes. The specific activity at a corrected electrode potential of $0.9 \mathrm{~V} v s$. RHE was intercept of the Koutecky-Levich plot, in which the inverse current density $(1 / \mathrm{j})$ was plotted as a function of the inverse of the square root of the rotation rate $\left(\omega^{1 / 2}\right)$ using the polarization curves from the prepared electrocatalyst. Figure S5 shows the linear sweep voltammograms (LSVs) of the electrocatalysts studied in this project.

Table S2 summarizes the ECAs and ORR activities. The PtCo/C-HT-600h exhibited the highest area-specific activity, which was 10 times higher than that of the $\mathrm{Pt} / \mathrm{C}$. Although the specific activity of the $\mathrm{PtCo} / \mathrm{C}$ was drastically enhanced by the heat treatment process, the area-specific activity of the $\mathrm{PtCu} / \mathrm{C}$-HT was not improved by the heat treatment. The area-specific activities of the untreated $\mathrm{PtCo} / \mathrm{C}, \mathrm{PtCu} / \mathrm{C}$, and $\mathrm{PtNi} / \mathrm{C}$ were almost equivalent and were approximately 4 to 5 times higher than that of the $\mathrm{Pt} / \mathrm{C}$. 


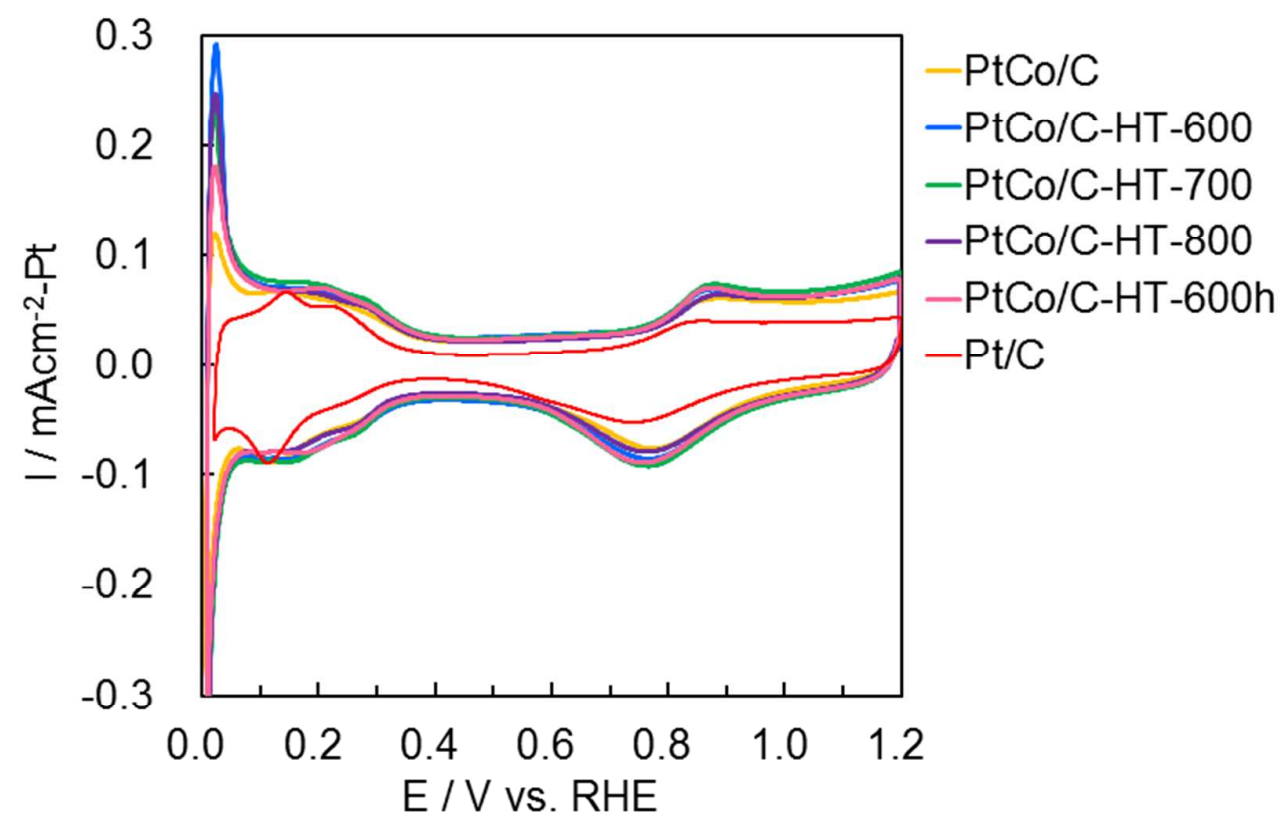

(a) $\mathrm{PtCo} / \mathrm{C}$ and $\mathrm{PtCo} / \mathrm{C}-\mathrm{HTs}$

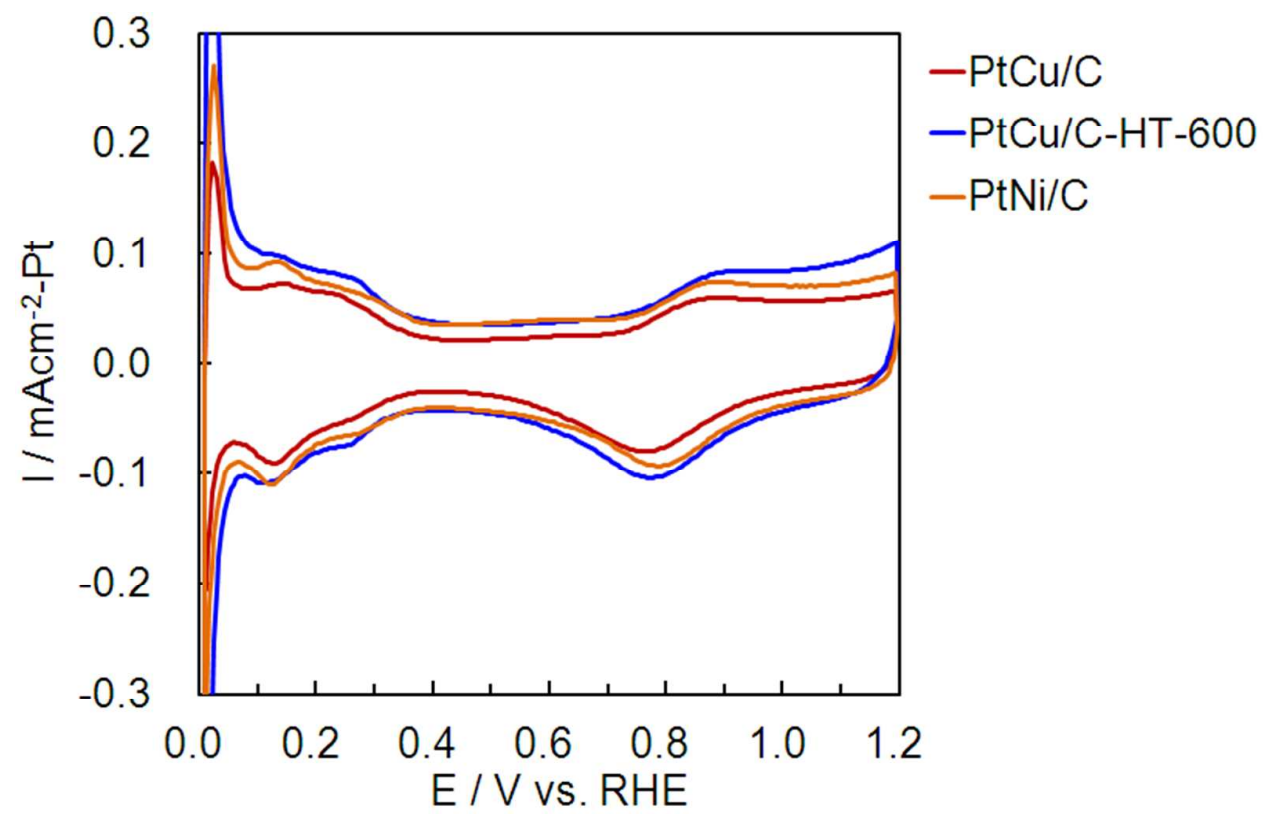

(b) $\mathrm{PtCu} / \mathrm{C}, \mathrm{PtCu} / \mathrm{C}-\mathrm{HT}$, and $\mathrm{PtNi} / \mathrm{C}$

Figure S4. Cyclic voltammograms of (a) $\mathrm{PtCo} / \mathrm{C}$ and $\mathrm{PtCo} / \mathrm{C}-\mathrm{HT}$ and (b) $\mathrm{PtCu} / \mathrm{C}, \mathrm{PtCu} / \mathrm{C}-\mathrm{HT}$, and $\mathrm{PtNi} / \mathrm{C}$. 


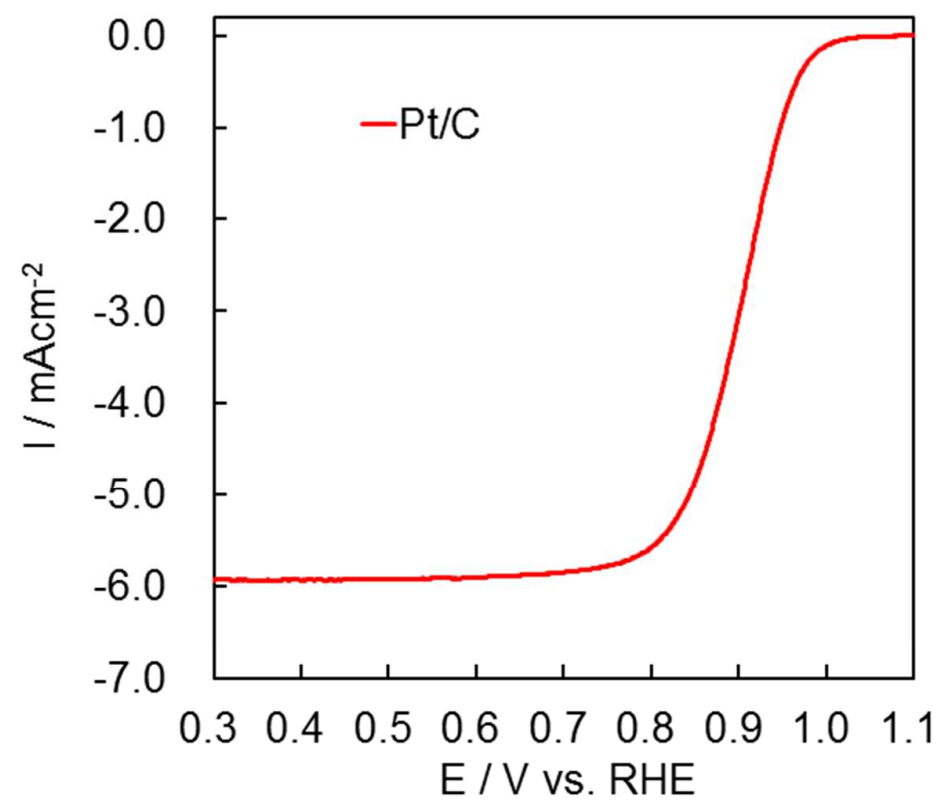

(a) $\mathrm{Pt} / \mathrm{C}$

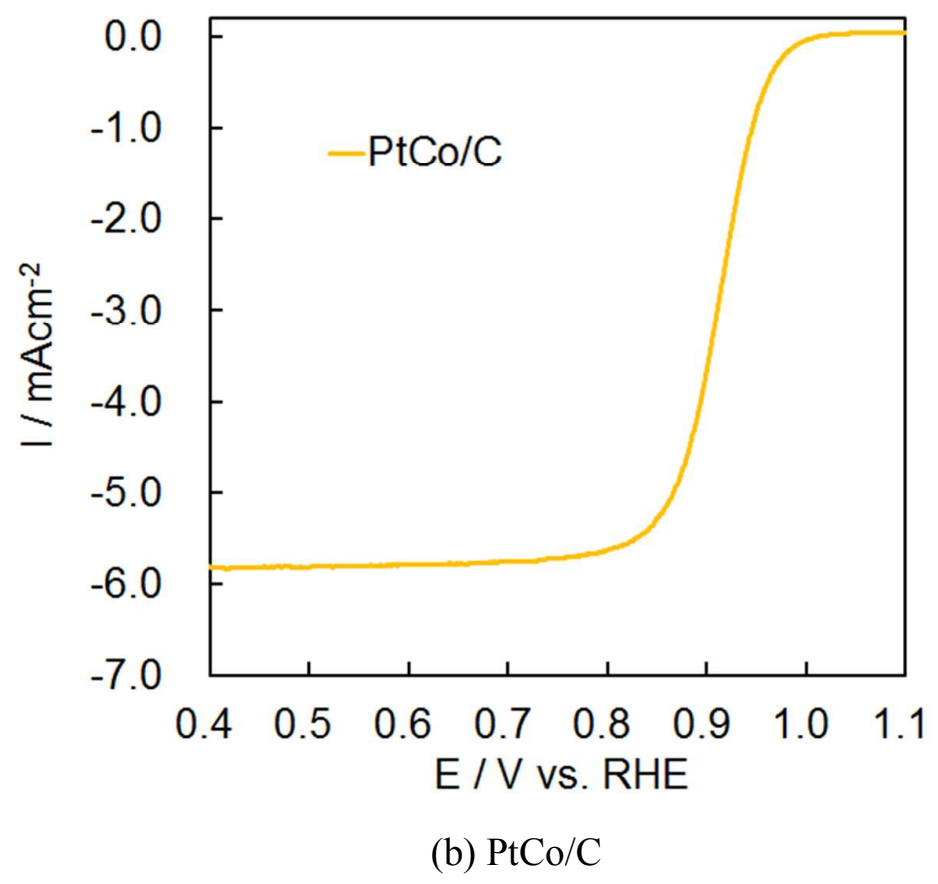

Figure S5-1. Linear sweep voltammograms of (a) $\mathrm{Pt} / \mathrm{C}$ and (b) $\mathrm{PtCo} / \mathrm{C}$. 


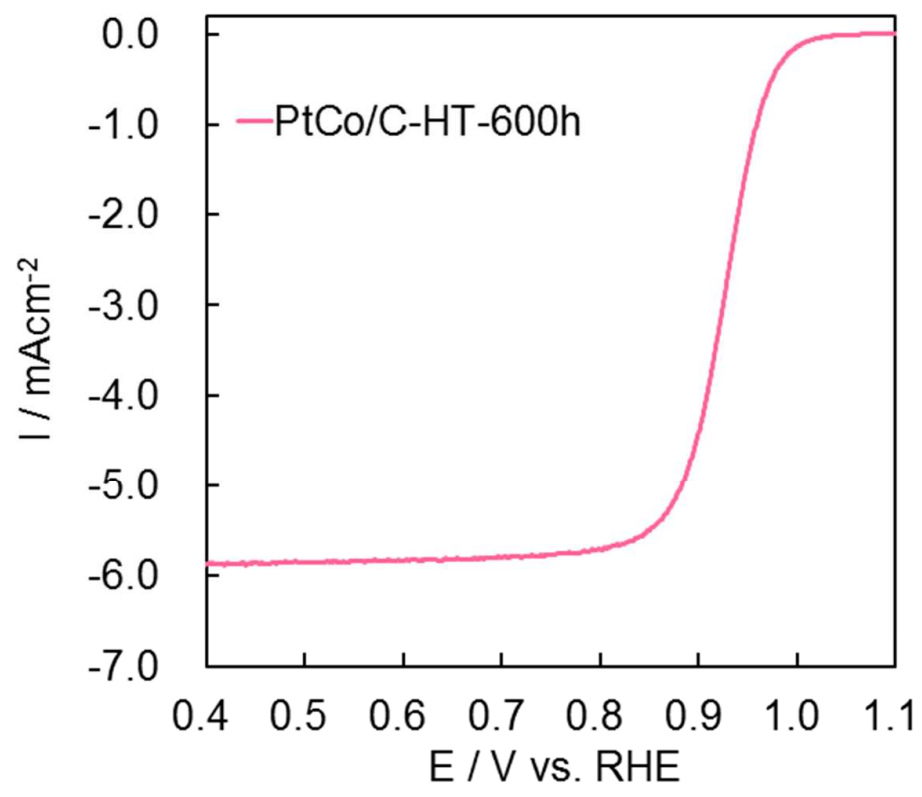

(c) $\mathrm{PtCo} / \mathrm{C}-\mathrm{HT}-600 \mathrm{~h}$

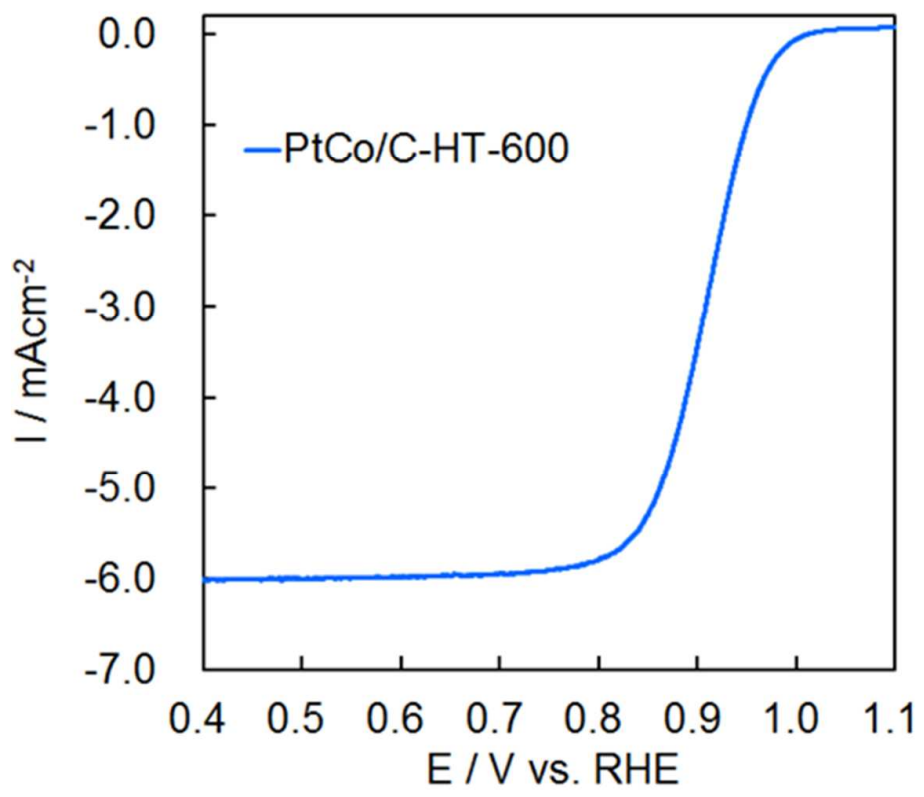

(d) $\mathrm{PtCo} / \mathrm{C}-\mathrm{HT}-600$

Figure S5-2. Linear sweep voltammograms of (c) PtCo/C-HT-600h and (d) PtCo/C-HT-600. 


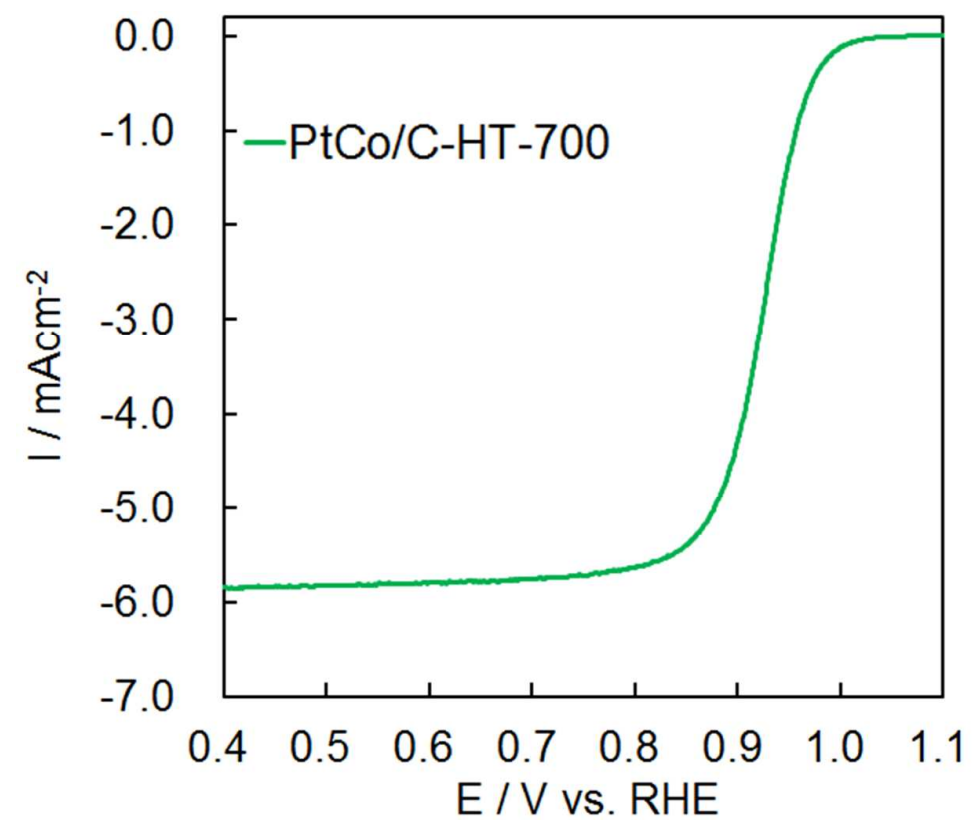

(e) $\mathrm{PtCo} / \mathrm{C}-\mathrm{HT}-700$

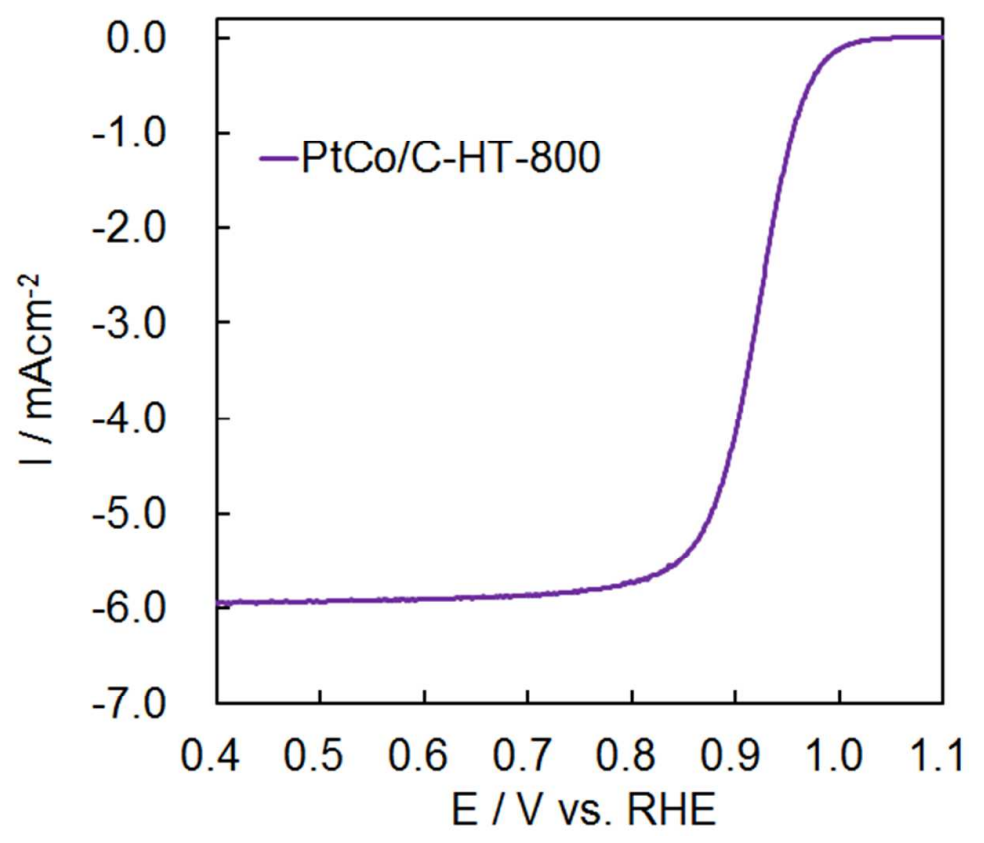

(f) $\mathrm{PtCo} / \mathrm{C}-\mathrm{HT}-800$

Figure S5-3. Linear sweep voltammograms of (a) PtCo/C-HT-700 and (b) PtCo/C-HT-800. 


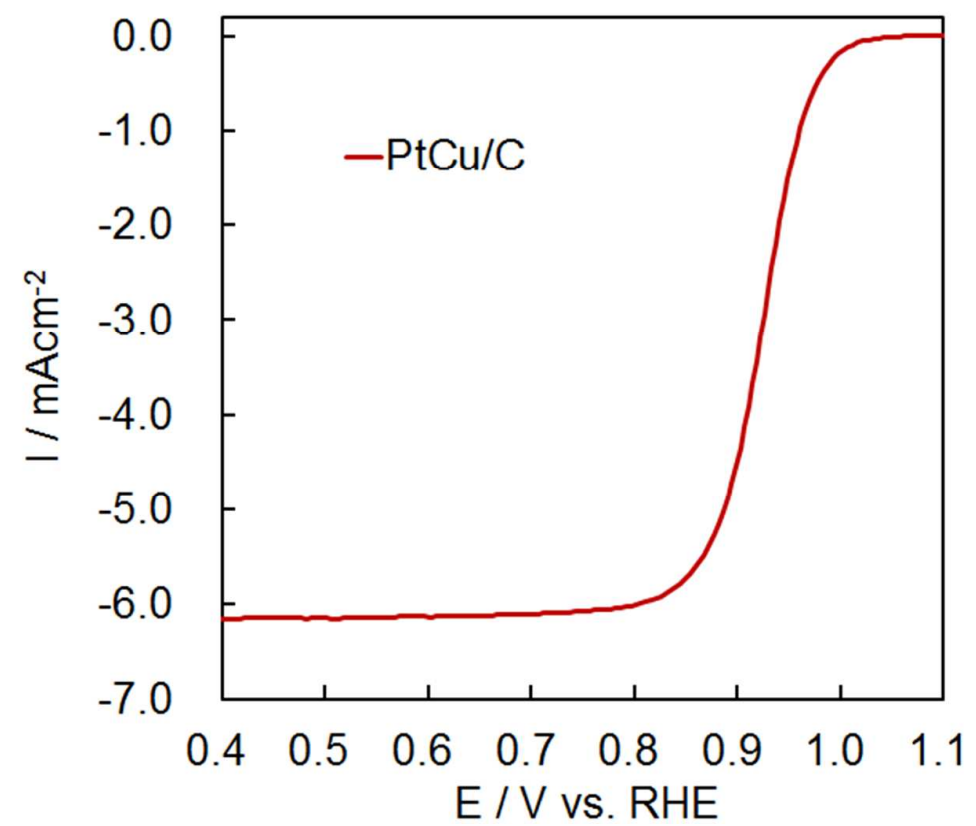

(g) $\mathrm{PtCu} / \mathrm{C}$

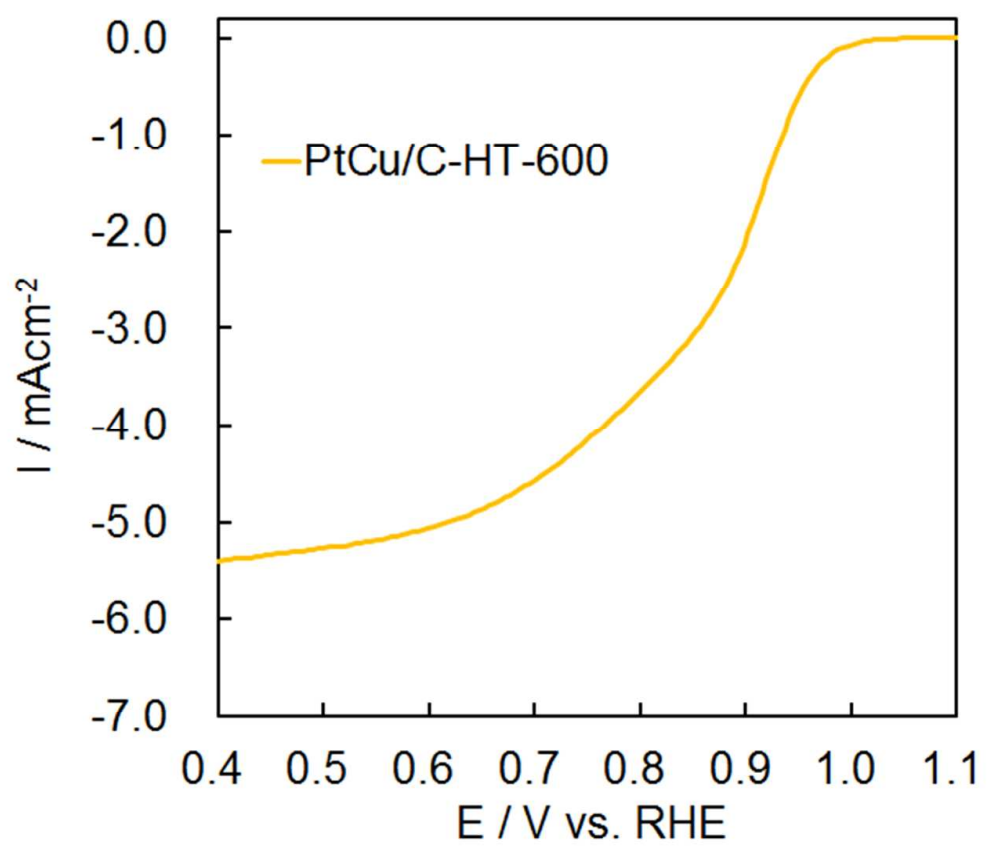

(h) $\mathrm{PtCu} / \mathrm{C}-\mathrm{HT}$

Figure S5-4. Linear sweep voltammograms of (g) PtCu/C and (h) PtCu/C-HT-600. 


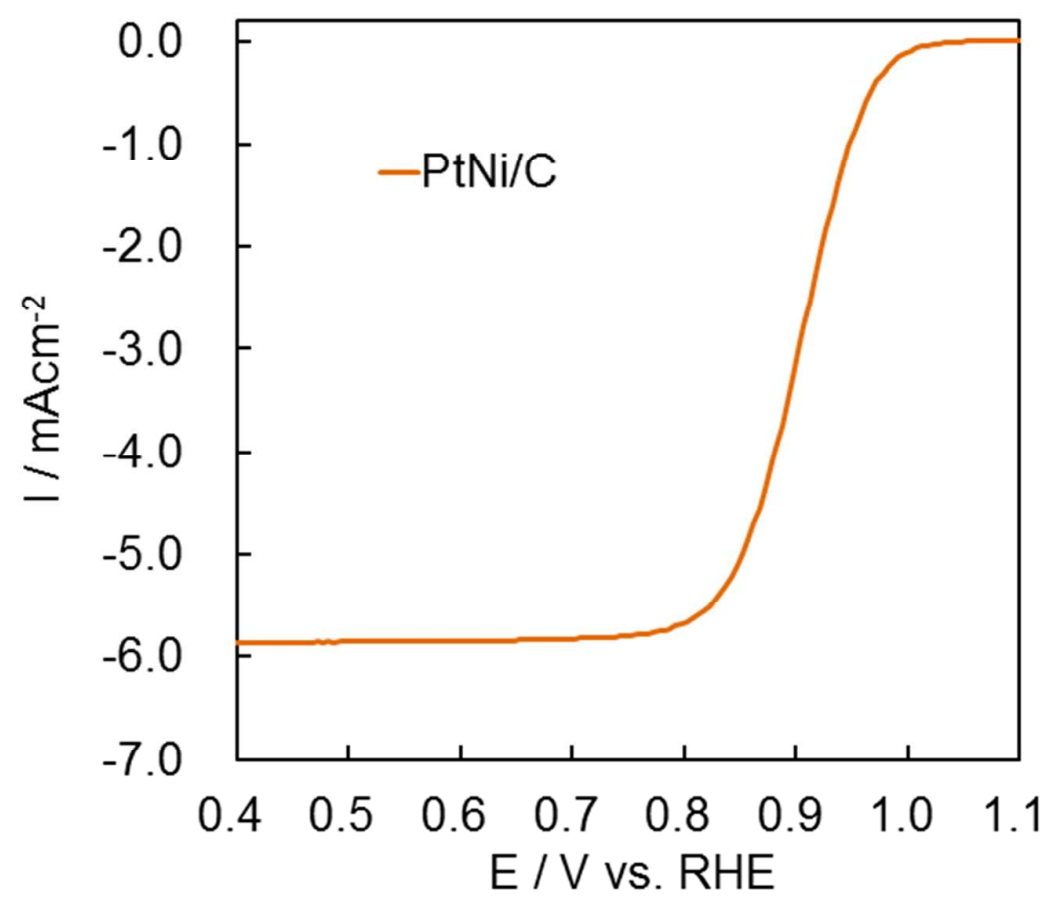

(i) $\mathrm{PtNi} / \mathrm{C}$

Figure S5-5. Linear sweep voltammogram of PtNi/C.

Table S2. ECAs and area-specific and mass-specific ORR activities of Pt/C, PtCo/C, PtCo/C-HT600, PtCo/C-HT-700, PtCo/C-HT-800, PtCo/C-HT-600h, PtCu/C, PtCu/C-HT-600, and PtNi/C electrocatalysts. The values in parentheses indicate the IR uncorrected activities.

\begin{tabular}{cccc}
\hline & ECA $/ \mathrm{m}^{2} \mathrm{~g}^{-1}$ & Area specific activity $/ \mathrm{mAcm}^{-2}$ & Mass specific activity $/ \mathrm{Akg}^{-1}$ \\
$\mathrm{Pt} / \mathrm{C}$ & 84 & $0.53(0.30)$ & 0.43 \\
$\mathrm{PtCo} / \mathrm{C}$ & 44 & $2.4(1.0)$ & 1.0 \\
$\mathrm{PtCo} / \mathrm{C}-\mathrm{HT}-600$ & 45 & $4.3(1.6)$ & 1.9 \\
$\mathrm{PtCo} / \mathrm{C}-\mathrm{HT}-700$ & 42 & $4.6(1.8)$ & 2.0 \\
$\mathrm{PtCo} / \mathrm{C}-\mathrm{HT}-800$ & 43 & $3.6(1.5)$ & 1.5 \\
$\mathrm{PtCo} / \mathrm{C}-\mathrm{HT}-600 \mathrm{~h}$ & 49 & $5.2(1.8)$ & 2.6 \\
$\mathrm{PtCu} / \mathrm{C}$ & 59 & $2.0(0.79)$ & 1.2 \\
$\mathrm{PtCu} / \mathrm{C}-\mathrm{HT}-600$ & 28 & $2.2(1.5)$ & 0.61 \\
$\mathrm{PtNi} / \mathrm{C}$ & 31 & $2.7(1.1)$ & 0.86 \\
\hline \hline
\end{tabular}


7. XANES analyses of $\mathrm{PtCo} / \mathrm{C}, \mathrm{PtCo} / \mathrm{C}-\mathrm{HTs}, \mathrm{PtCu} / \mathrm{C}, \mathrm{PtCu} / \mathrm{C}-\mathrm{HT}$, and $\mathrm{PtNi} / \mathrm{C}$ electrocatalysts

Figure S6 presents the Co K-edge XANES spectra of the $\mathrm{PtCo} / \mathrm{C}$ and $\mathrm{PtCo} / \mathrm{C}-\mathrm{HT}$ samples at 0.4 $\mathrm{V} v$ s. RHE, together with standard spectra obtained from Co foil, $\mathrm{CoO}$ powder, and PtCo alloy foil. The $\mathrm{Co} \mathrm{K}$-edge of the $\mathrm{PtCo} / \mathrm{C}$ had a rather large absorption edge peak. In addition, the peak energy of the $\mathrm{PtCo} / \mathrm{C}$ was close to that of the $\mathrm{CoO}$ reference sample. Hence, the majority of the Co atoms in the $\mathrm{PtCo} / \mathrm{C}$ were not metallic but somewhat oxidized. This oxidized state is one reason for the ready dissolution of $\mathrm{Co}$ atoms to form the $\mathrm{PtCo} / \mathrm{C}$ electrocatalyst. Hence the durability of this material was lower than that of the heat-treated PtCo/C-HT samples. In contrast, the Co XANES data of the $\mathrm{PtCo} / \mathrm{C}-\mathrm{HT}$ specimens were significantly changed, such that the edge peak heights decreased and the edge positions were shifted to lower energy with increasing heat treatment temperatures. The edge and peak shoulders appeared at 7722 and $7728 \mathrm{eV}$, resembling the spectrum of the PtCo foil. The XANES data obtained from the PtCo/C-HT samples were different from that of the Co foil, which had two peaks at 7723 and $7732 \mathrm{eV}$. The heat treatment thus effectively reduced the Co species to form PtCo alloy particles.

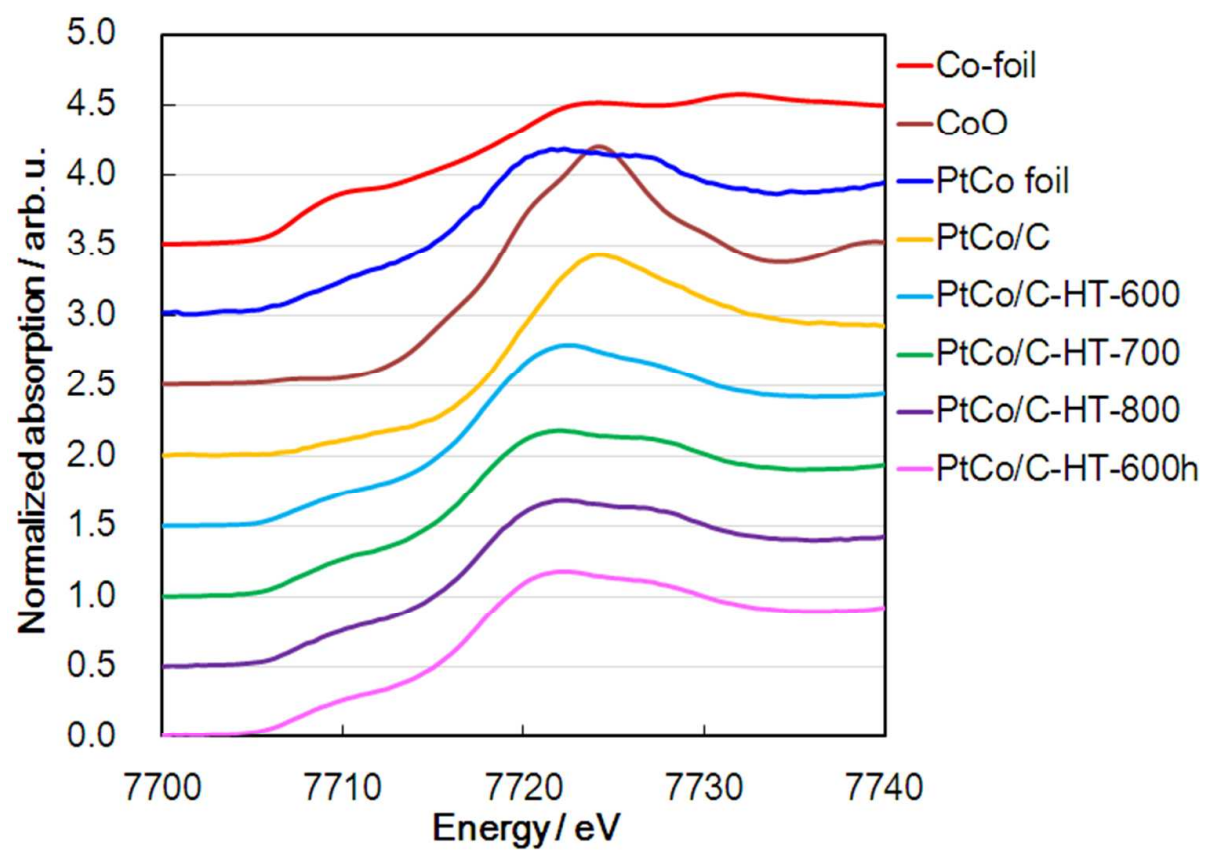

Figure S6. Co K-edge XANES spectra of $\mathrm{Co}$ foil, $\mathrm{CoO}$ reference powder, $\mathrm{PtCo}$ alloy foil, $\mathrm{PtCo} / \mathrm{C}$, PtCo/C-HT-600, PtCo/C-HT-700, PtCo/C-HT-800, and PtCo/C-HT-600h at 0.4 V vs. RHE. 
Figure $\mathrm{S} 7$ shows $\mathrm{Cu}$ K-edge XANES spectra of the $\mathrm{PtCu} / \mathrm{C}$ and $\mathrm{PtCu} / \mathrm{C}-\mathrm{HT}$ at $0.4 \mathrm{~V}$ vs. RHE, together with standard spectra obtained from $\mathrm{PtCu}$ alloy foil and $\mathrm{Cu}$ foil. The XANES spectrum of the $\mathrm{PtCu} / \mathrm{C}$ was similar to that of the $\mathrm{PtCu}$ foil, although the edge peak height generated by the $\mathrm{PtCu} / \mathrm{C}$ was not as high as that of $\mathrm{CuO}$ or $\mathrm{Cu}_{2} \mathrm{O}$ as reported by Gaur et al. ${ }^{6}$ The $\mathrm{Cu}$ atoms in the untreated $\mathrm{PtCu} / \mathrm{C}$ were not greatly oxidized compared with the $\mathrm{Co}$ atoms in the $\mathrm{PtCo} / \mathrm{C}$. In addition, the $\mathrm{Cu}$ atoms were relatively well alloyed despite the lack of heat treatment. The stability of the $\mathrm{PtCu}$ nanoparticles in the $\mathrm{PtCu} / \mathrm{C}$ could prevent the dissolution of $\mathrm{Cu}$ species from the $\mathrm{PtCu}$ nanoparticles. Following heat treatment, the edge peak height was increased and its position shifted slightly to lower energy, while the shape of the spectrum became identical to that of the PtCu foil. Therefore, the heat treatment process was considered to be an effective means of alloying.

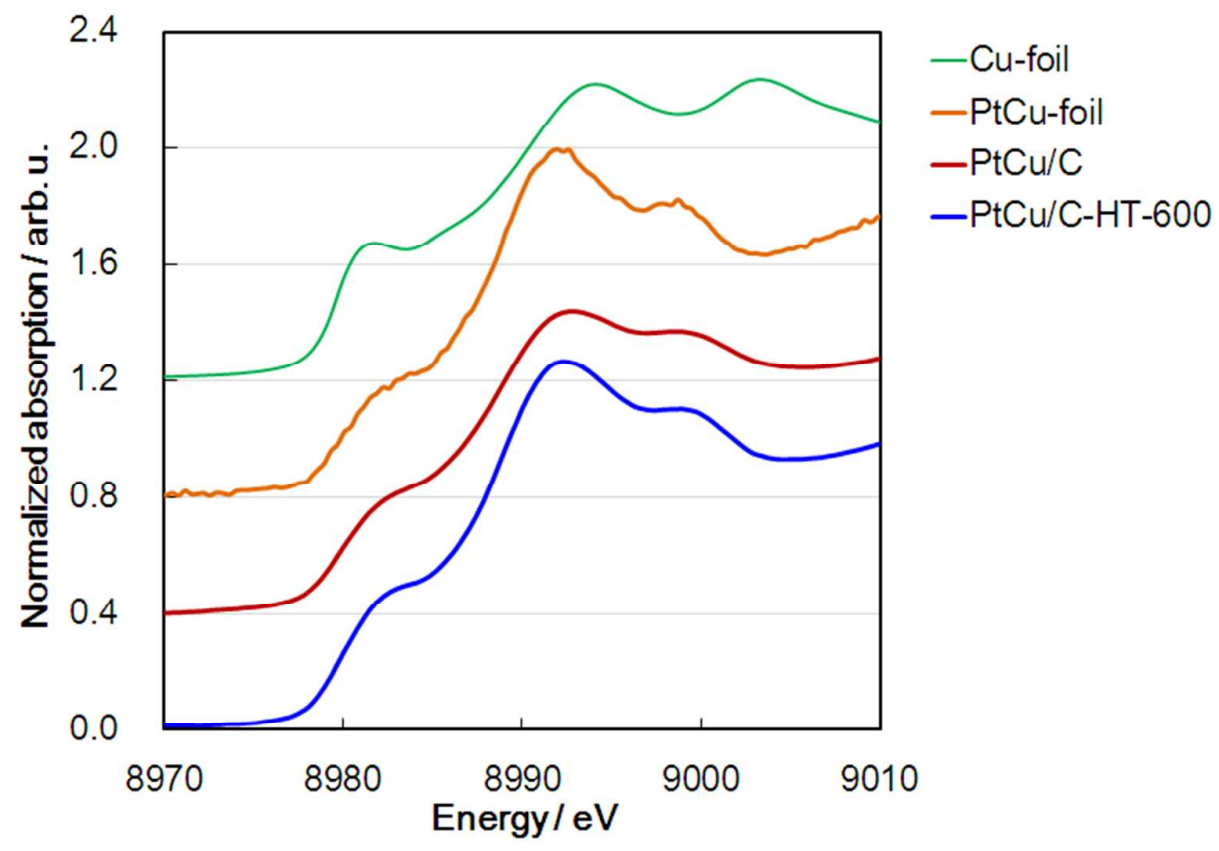

Figure S7. Cu K-edge XANES spectra of $\mathrm{Cu}$ foil, PtCo alloy foil, $\mathrm{PtCu} / \mathrm{C}$, and $\mathrm{PtCu} / \mathrm{C}-\mathrm{HT}-600$ at $0.4 \mathrm{~V} v s$. RHE. 
Figure S8 shows the Ni K-edge XANES spectra of PtNi/C at $0.4 \mathrm{~V}$ vs. RHE together with standard spectra of PtNi alloy foil, $\mathrm{Ni}$ foil, and $\mathrm{NiO}$ reference powder. The edge peak height and energy of the $\mathrm{PtNi} / \mathrm{C}$ were close to those of the $\mathrm{NiO}$ particle, hence the $\mathrm{Ni}$ atoms in the $\mathrm{PtNi} / \mathrm{C}$ were largely oxidized and in a different state from those in the PtNi alloy foil.

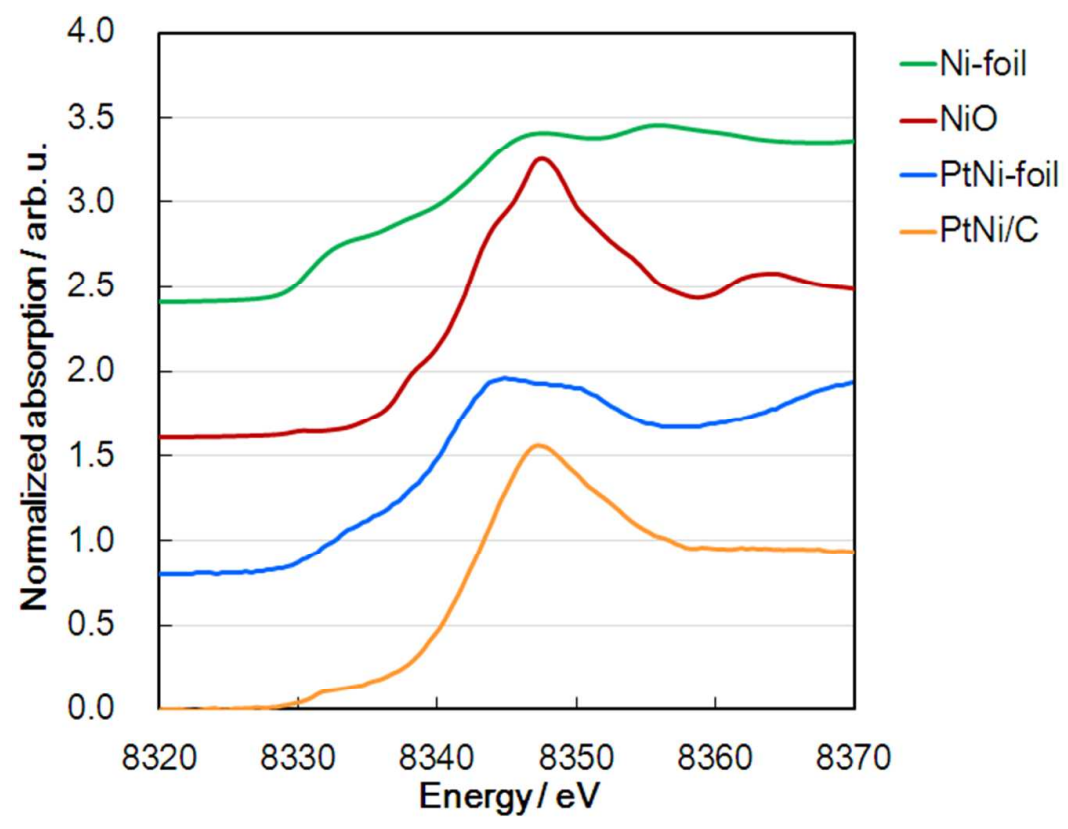

Figure S8. Ni K-edge XANES spectra of Ni foil, NiO reference powder, PtNi alloy foil, and PtNi/C at $0.4 \mathrm{~V} v s$. RHE. 
Table S3 and Figure S9 show the Pt d vacancy calculated from the Figures 5 and 6 in the main text.

Table S3. Pt 5d vacancies of $\mathrm{Pt}$ foil, $\mathrm{Pt} / \mathrm{Co}, \mathrm{PtCu}, \mathrm{PtNi}$ random alloy foil, $\mathrm{Pt} / \mathrm{C}, \mathrm{PtCo} / \mathrm{C}, \mathrm{PtCo} / \mathrm{C}-$ $\mathrm{HTs}, \mathrm{PtCu} / \mathrm{C}, \mathrm{PtCu} / \mathrm{C}-\mathrm{HT}$, and $\mathrm{PtNi} / \mathrm{C}$ at $0.4 \mathrm{~V} v s$. RHE. The uncertainties were calculated from the errors in the determined area sizes of the Pt $\mathrm{L}_{\mathrm{II}}$ and $\mathrm{L}_{\mathrm{III}}$-edge XANES spectra.

\begin{tabular}{cc}
\hline \hline Sample & Pt 5d vacancy \\
\hline Pt foil & 0.300 \\
\hline PtCo foil & $0.302 \pm 0.031$ \\
\hline PtCu foil & $0.306 \pm 0.029$ \\
\hline PtNi foil & $0.303 \pm 0.030$ \\
\hline Pt/C & $0.309 \pm 0.031$ \\
\hline PtCo/C & $0.312 \pm 0.031$ \\
\hline $\mathrm{PtCo} / \mathrm{C}-\mathrm{HT}-600$ & $0.313 \pm 0.031$ \\
\hline $\mathrm{PtCo} / \mathrm{C}-\mathrm{HT}-700$ & $0.311 \pm 0.031$ \\
\hline $\mathrm{PtCo} / \mathrm{C}-\mathrm{HT}-800$ & $0.313 \pm 0.031$ \\
\hline $\mathrm{PtCo} / \mathrm{C}-\mathrm{HT}-600 \mathrm{~h}$ & $0.313 \pm 0.031$ \\
\hline $\mathrm{PtCu} / \mathrm{C}$ & $0.305 \pm 0.030$ \\
\hline $\mathrm{PtCu} / \mathrm{C}-\mathrm{HT}$ & $0.305 \pm 0.030$ \\
\hline $\mathrm{PtNi} / \mathrm{C}$ & $0.303 \pm 0.030$ \\
\hline
\end{tabular}

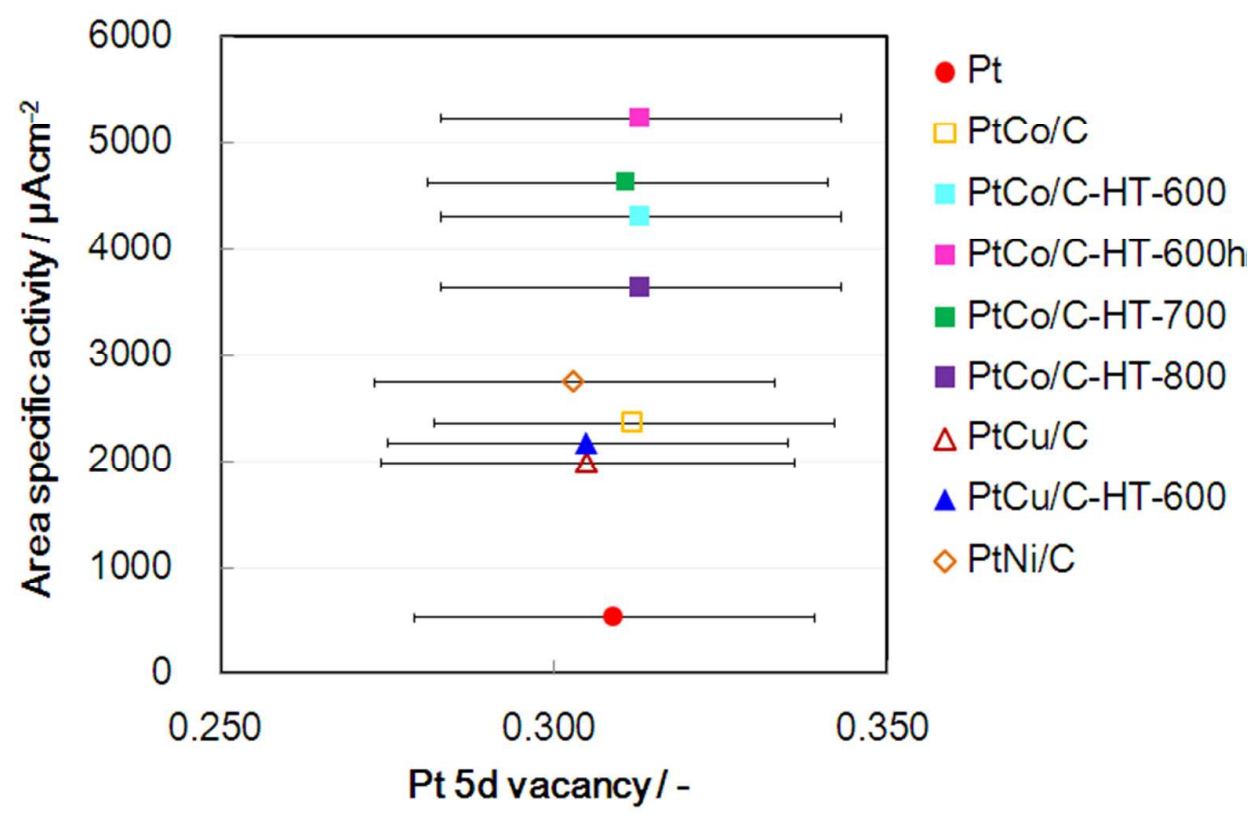

Figure S9. Correlation between the Pt 5d vacancies of the prepared electrocatalysts from Table 3 and the area-specific activities of these samples from Table S2. 
8. XAFS analysis of reference foils and the $\mathrm{Pt} / \mathrm{C}$ base electrocatalyst

Table S4 provides the bond distances, coordination numbers and Debye-Waller factors obtained using FEFF-derived phase shifts and amplitude functions.

The Co-Co distance in the PtCo random alloy foil was $0.263 \pm 0.004 \mathrm{~nm}$, a value that was much longer than that in Co foil. The Pt-Pt distance of the PtCo random alloy foil was $0.275 \pm 0.001 \mathrm{~nm}$, which was somewhat shorter than that found in Pt foil, while the Co-Pt distance of $0.269 \pm 0.001$ $\mathrm{nm}$ was equal to the average value of the Co-Co and Pt-Pt distances in the alloy foil.

The $\mathrm{Cu}-\mathrm{Cu}$ distance in the $\mathrm{PtCu}$ random alloy foil was $0.266 \pm 0.003 \mathrm{~nm}$, which is much longer than that of the $\mathrm{Cu}$ foil, as in the case of the PtCo foil. The Pt-Pt distance in the PtCu random alloy foil was $0.274 \pm 0.001 \mathrm{~nm}$, and so some contraction of the Pt-Pt distance occurred. The Pt-Cu distance was found to be $0.269 \pm 0.003 \mathrm{~nm}$, a slightly longer value than expected based on the average $\mathrm{Cu}-\mathrm{Cu}$ and Pt-Pt distances in the PtCo alloy foil. The Ni-Ni distance in the PtNi random alloy foil was $0.258 \pm 0.004 \mathrm{~nm}$, which was much longer than that of the Ni foil, mirroring the relationship between the PtCo and $\mathrm{PtCu}$ foil. The Pt-Pt distance in the PtNi random alloy foil was $0.275 \pm 0.001 \mathrm{~nm}$, thus a slight contraction of the Pt-Pt distance was observed. The Pt-Ni distance was found to be $0.265 \pm 0.002 \mathrm{~nm}$, a value that was longer than that anticipated based on the average Ni-Ni and Pt-Pt distances, just as in the case of the PtCo and PtCu alloy foils.

Table S4 also shows the structural parameters of the $\mathrm{Pt} / \mathrm{C}$ reference electrocatalyst. The Pt-Pt distance in this material was $0.275 \pm 0.001 \mathrm{~nm}$, a value that was slightly shorter than that in the $\mathrm{Pt}$ foil. The coordination number obtained for this material was reasonable, based on an average particle diameter of $2.2 \mathrm{~nm}$ and assuming a cuboctahedron structure. 
Table S4. Curve fitting parameters for reference $\mathrm{Pt}, \mathrm{Co}, \mathrm{Cu}$ and $\mathrm{Ni}$ foils, $\mathrm{PtCo}, \mathrm{PtCu}$, and $\mathrm{PtNi}$ random alloy foils and a Pt/C electrocatalyst at $0.4 \mathrm{~V}$ vs. RHE.

\begin{tabular}{|c|c|c|c|c|c|}
\hline Sample & Edge & Bond & $\begin{array}{l}\text { Coordination } \\
\text { number }\end{array}$ & $\begin{array}{l}\text { Interatomic distance / } \\
\mathrm{nm}\end{array}$ & $\begin{array}{c}\text { Debye-Waller factor } / \\
\mathrm{nm}\end{array}$ \\
\hline Pt foil & Pt-L & $\mathrm{Pt}-\mathrm{Pt}$ & $(12)$ & $0.276 \pm 0.001$ & $0.0070 \pm 0.0001$ \\
\hline Co foil & Co-K & Co-Co & $(12)$ & $0.249 \pm 0.001$ & $0.0072 \pm 0.0001$ \\
\hline $\mathrm{Cu}$ foil & $\mathrm{Cu}-\mathrm{K}$ & $\mathrm{Cu}-\mathrm{Cu}$ & (12) & $0.253 \pm 0.001$ & $0.0083 \pm 0.0002$ \\
\hline Ni foil & $\mathrm{Ni}-\mathrm{K}$ & Ni-Ni & $(12)$ & $0.248 \pm 0.001$ & $0.0069 \pm 0.0002$ \\
\hline \multirow{4}{*}{$\begin{array}{c}\mathrm{Pt} / \mathrm{Co} \\
(9 / 1) \\
\text { foil }\end{array}$} & \multirow{2}{*}{ Pt-L } & $\mathrm{Pt}-\mathrm{Pt}$ & $10.8 \pm 0.8$ & $0.275 \pm 0.001$ & $0.0075 \pm 0.0001$ \\
\hline & & $\mathrm{Pt}-\mathrm{Co}$ & $1.0 \pm 0.6$ & $0.269 \pm 0.003$ & $0.0093 \pm 0.0027$ \\
\hline & \multirow{2}{*}{ Co-K } & $\mathrm{Co}-\mathrm{Co}$ & $1.1 \pm 0.6$ & $0.264 \pm 0.003$ & $0.0035 \pm 0.0035$ \\
\hline & & $\mathrm{Co}-\mathrm{Pt}$ & $10.4 \pm 1.3$ & $0.269 \pm 0.001$ & $0.0057 \pm 0.0005$ \\
\hline \multirow{4}{*}{$\begin{array}{c}\mathrm{Pt} / \mathrm{Cu} \\
(9 / 1) \\
\text { foil }\end{array}$} & \multirow{2}{*}{ Pt-L } & Pt-Pt & $10.3 \pm 0.9$ & $0.274 \pm 0.001$ & $0.0074 \pm 0.0002$ \\
\hline & & $\mathrm{Pt}-\mathrm{Cu}$ & $1.0 \pm 0.5$ & $0.269 \pm 0.003$ & $0.0078 \pm 0.0020$ \\
\hline & \multirow{2}{*}{$\mathrm{Cu}-\mathrm{K}$} & $\mathrm{Cu}-\mathrm{Cu}$ & $1.2 \pm 0.6$ & $0.266 \pm 0.003$ & $0.0045 \pm 0.0045$ \\
\hline & & $\mathrm{Cu}-\mathrm{Pt}$ & $10.5 \pm 1.5$ & $0.270 \pm 0.001$ & $0.0060 \pm 0.0006$ \\
\hline \multirow{4}{*}{$\begin{array}{c}\mathrm{Pt} / \mathrm{Ni} \\
(9 / 1) \\
\text { foil }\end{array}$} & \multirow{2}{*}{ Pt-L $L_{\text {III }}$} & Pt-Pt & $10.8 \pm 0.6$ & $0.275 \pm 0.001$ & $0.0073 \pm 0.0001$ \\
\hline & & Pt-Ni & $1.1 \pm 0.4$ & $0.265 \pm 0.002$ & $0.0073 \pm 0.0015$ \\
\hline & \multirow{2}{*}{$\mathrm{Ni}-\mathrm{K}$} & $\mathrm{Ni}-\mathrm{Ni}$ & $1.4 \pm 0.8$ & $0.258 \pm 0.004$ & $0.0045 \pm 0.0045$ \\
\hline & & $\mathrm{Ni}-\mathrm{Pt}$ & $10.0 \pm 1.9$ & $0.265 \pm 0.002$ & $0.0073 \pm 0.0009$ \\
\hline $\mathrm{Pt} / \mathrm{C}$ & Pt-L $L_{I I I}$ & $\mathrm{Pt}-\mathrm{Pt}$ & $9.1 \pm 1.6$ & $0.275 \pm 0.001$ & $0.0084 \pm 0.0004$ \\
\hline
\end{tabular}

9. Detailed discussion of the PtCo/C electrocatalyst based on XAFS and XRD data

Figure $\mathrm{S} 3$ exhibits a small peak at $33^{\circ}$ that originates from the $\mathrm{Pt}_{3} \mathrm{Co}$ intermetallic structure. To clarify the structure of the $\mathrm{PtCo} / \mathrm{C}-\mathrm{HT}-600,-700$ and -800 materials, which were not perfect $\mathrm{Pt}_{3} \mathrm{Co}$ intermetallic ordered structures, the Hamilton method was applied with the assumption that the CoCo coordination number should be zero. The R-factors obtained from one shell or two shell curve fittings and the confidence levels of rejection are shown in Table S5. The validity of the two shell curve fitting was suitable according to the Hamilton method and a $\mathrm{Pt}_{3} \mathrm{Co}$ intermetallic structure was rejected at a confidence level greater than $95 \%$ in the case of the PtCo/C-HT-600 and -800 specimens. However, intermetallic $\mathrm{Pt}_{3} \mathrm{Co}$-like atomic ordering might be present to some extent because a corresponding peak was observed in the XRD data. The $\mathrm{Pt}_{3} \mathrm{Co}$ intermetallic compound structure has the fcc crystal lattice illustrated in Figure S10, in which the Co is situated at the face center position of the (100) plane. In this work, XRD patterns were simulated and the $\mathrm{Pt}_{3} \mathrm{Co}$ intermetallic peak could be reproduced even if only $40 \%$ of the Co sites were exchanged with $\mathrm{Pt}$ sites in the $\mathrm{Pt}_{3} \mathrm{Co}$ nanoparticles. The coordination numbers of the $\mathrm{Pt}$ and Co site-exchanged $\mathrm{Pt}_{3} \mathrm{Co}$ structures given in Table S6 are in good agreement with the EXAFS coordination numbers within the uncertainties in Table 2. As described above, considering both XRD and EXAFS data, we can conclude that the $\mathrm{Pt}_{3} \mathrm{Co}$ nanoparticles had an ordered $\mathrm{Pt}_{3} \mathrm{Co}$ structure in which $\mathrm{Co}$ or $\mathrm{Pt}$ atoms 
(about $40 \%$ ) were partially exchanged with the other elements in the $\mathrm{PtCo} / \mathrm{C}-\mathrm{HT}$. Hence, it is believed that partial ordering took place in our samples during heat treatment, as has also been reported by Wang et al. ${ }^{7}$ This work thus demonstrated that XRD analysis is not sufficient to establish the formation of a perfect intermetallic compound but rather that a combination of XAFS and $\mathrm{XRD}$ is necessary.

Table S5. Co K-edge one shell and two shell curve fitting R factors for PtCo/C-HT-600, -700 and -800 at $0.4 \mathrm{~V} v s$. RHE.

\begin{tabular}{cccc}
\hline \hline Sample & $\begin{array}{c}\text { R factor for two } \\
\text { shells }\end{array}$ & $\begin{array}{c}\mathrm{R} \text { factor for one } \\
\text { shell }\end{array}$ & $\begin{array}{c}\text { Confidence level for } \mathrm{Pt}_{3} \mathrm{Co} \\
\text { intermetallic rejection }\end{array}$ \\
\hline $\mathrm{PtCo} / \mathrm{C}-\mathrm{HT}-600$ & 1.2 & 7.2 & $99.5 \%$ \\
\hline $\mathrm{PtCo} / \mathrm{C}-\mathrm{HT}-700$ & 2.3 & 4.6 & $90.0 \%$ \\
\hline $\mathrm{PtCo} / \mathrm{C}-\mathrm{HT}-800$ & 8.4 & 15.0 & $97.5 \%$ \\
\hline \hline
\end{tabular}

Table S6. Coordination numbers for $\mathrm{Pt}_{3} \mathrm{Co}$ intermetallic model particles in which $40 \%$ of Co atom positions are replaced with $\mathrm{Pt}$ atoms.

\begin{tabular}{ccccc}
\hline Model & Co-Co & Co-Pt & Pt-Co & Pt-Pt \\
\hline $\mathrm{Pt}_{3}$ Co intermetallic & 0 & 10.6 & 3.6 & 7.1 \\
\hline $40 \%$ & 2.1 & 8.5 & 2.9 & 7.9 \\
\hline $\mathrm{Pt}_{3}$ Co random alloy & 2.7 & 8.0 & 2.8 & 8.0 \\
\hline \hline
\end{tabular}


10. $\mathrm{Pt}_{3} \mathrm{Co}$ intermetallic compound structure

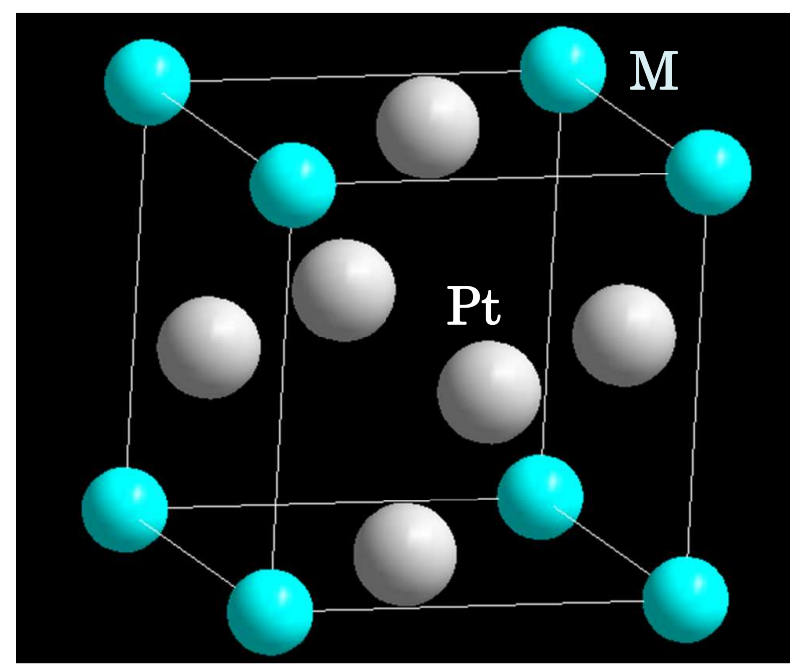

Figure S10. Structural model of the $\mathrm{Pt}_{3} \mathrm{Co} \mathrm{L}_{2}$ intermetallic. 
11. Model structures for PtNi, PtCo, and $\mathrm{PtCu}$ electrocatalysts

(a)

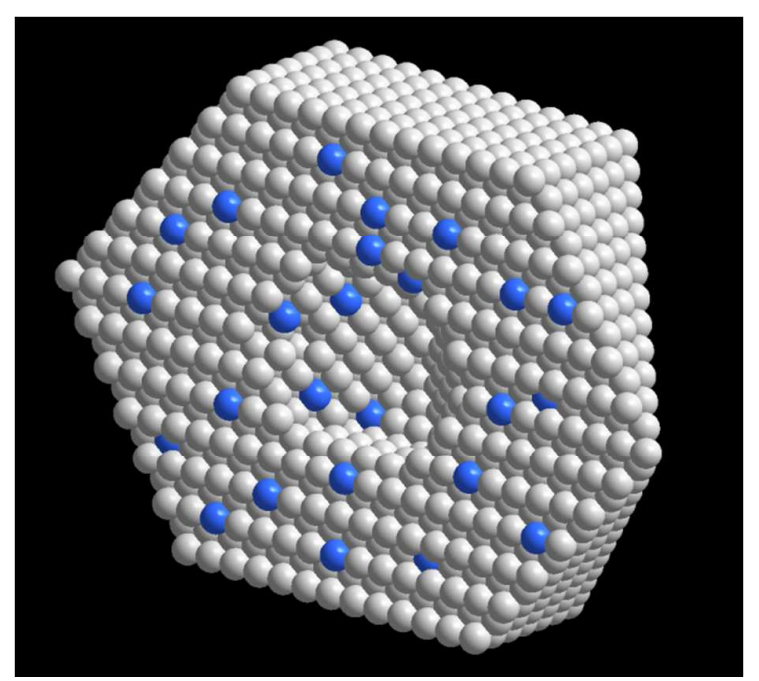

(b)

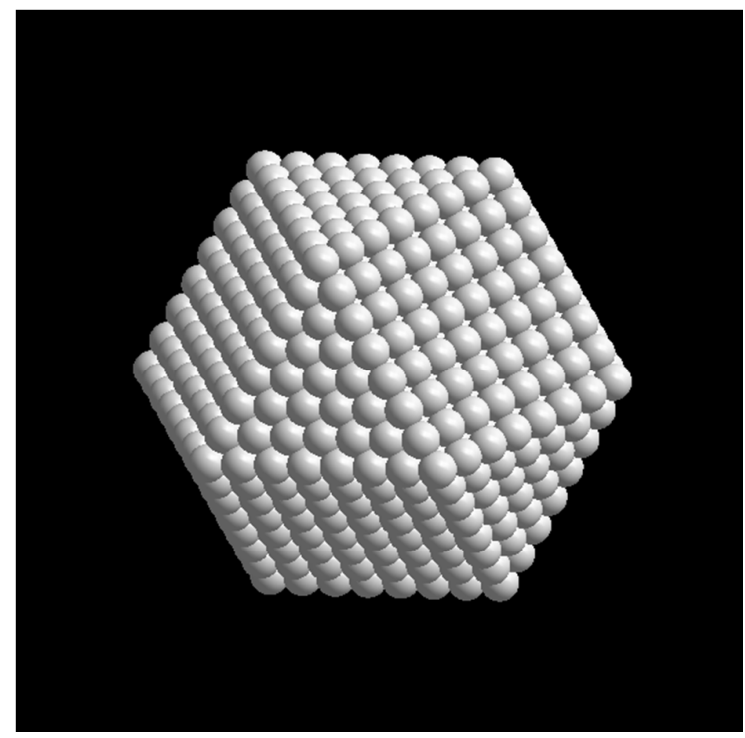

Figure S11. (a) PtNi model structure (Cross-section showing the hollow structure. Edge atoms form 13 and 6 shells around the hollow region. Blue atoms correspond to Ni.) and (b) $\mathrm{PtCo}$ or $\mathrm{PtCu}$ structure (Cuboctahedron with an 8-atom edge structure.). 
12. Numbers of edge atoms, particle sizes, and coordination numbers of electrocatalyst particles

The prepared electrocatalysts were modeled as cuboctahedron nanoparticles and the resulting numbers of edge atoms were provided in Table S7. The corresponding electrocatalysts in the present study were also shown.

Table S7. Numbers of edge atoms, total atoms, dispersions, particle sizes, and coordination numbers. (Dispersion calculated as the ratio of surface atoms.)

\begin{tabular}{rrrrrl}
\hline \hline $\begin{array}{l}\text { Number } \\
\text { of edge } \\
\text { atoms }\end{array}$ & $\begin{array}{l}\text { Number } \\
\text { of total } \\
\text { atoms }\end{array}$ & Dispersion & $\begin{array}{l}\text { Particle size } / \AA \\
\left(\mathrm{R}_{\mathrm{Pt}-\mathrm{Pt}}=2.78 \AA\right)\end{array}$ & $\begin{array}{l}\text { Coordination } \\
\text { number }\end{array}$ & $\begin{array}{l}\text { Corresponding } \\
\text { electrocatalyst in this } \\
\text { study }\end{array}$ \\
\hline 2 & 13 & 0.9231 & 8.34 & 5.538 & \\
\hline 3 & 55 & 0.7636 & 13.90 & 7.855 & \\
\hline 4 & 147 & 0.6259 & 19.46 & 8.980 & \\
\hline 5 & 309 & 0.5243 & 25.02 & 9.631 & $\mathrm{PtCo} / \mathrm{C}, \mathrm{PtCu} / \mathrm{C}, \mathrm{Pt} / \mathrm{C}$ \\
\hline 6 & 561 & 0.4492 & 30.58 & 10.05 & \\
\hline 7 & 923 & 0.3922 & 36.14 & 10.35 & \\
\hline 8 & 1415 & 0.3477 & 41.70 & 10.57 & $\mathrm{PtCu} / \mathrm{C}-\mathrm{HT}, \mathrm{PtCo} / \mathrm{C} \mathrm{HT}$ \\
\hline 9 & 2057 & 0.3121 & 47.26 & 10.73 & \\
\hline 10 & 2869 & 0.2830 & 52.82 & 10.87 & \\
\hline 11 & 3871 & 0.2588 & 58.38 & 10.97 & \\
\hline 12 & 5083 & 0.2384 & 63.94 & 11.06 & \\
\hline 13 & 6525 & 0.2210 & 69.50 & 11.14 & $\mathrm{PtNi} / \mathrm{C}$ \\
\hline 14 & 8217 & 0.2059 & 75.06 & 11.20 & \\
\hline 15 & 10179 & 0.1928 & 80.62 & 11.26 & \\
\hline 16 & 12431 & 0.1812 & 86.18 & 11.30 & \\
\hline \hline
\end{tabular}


13. Correlation between ORR activity and bond length based on literature data

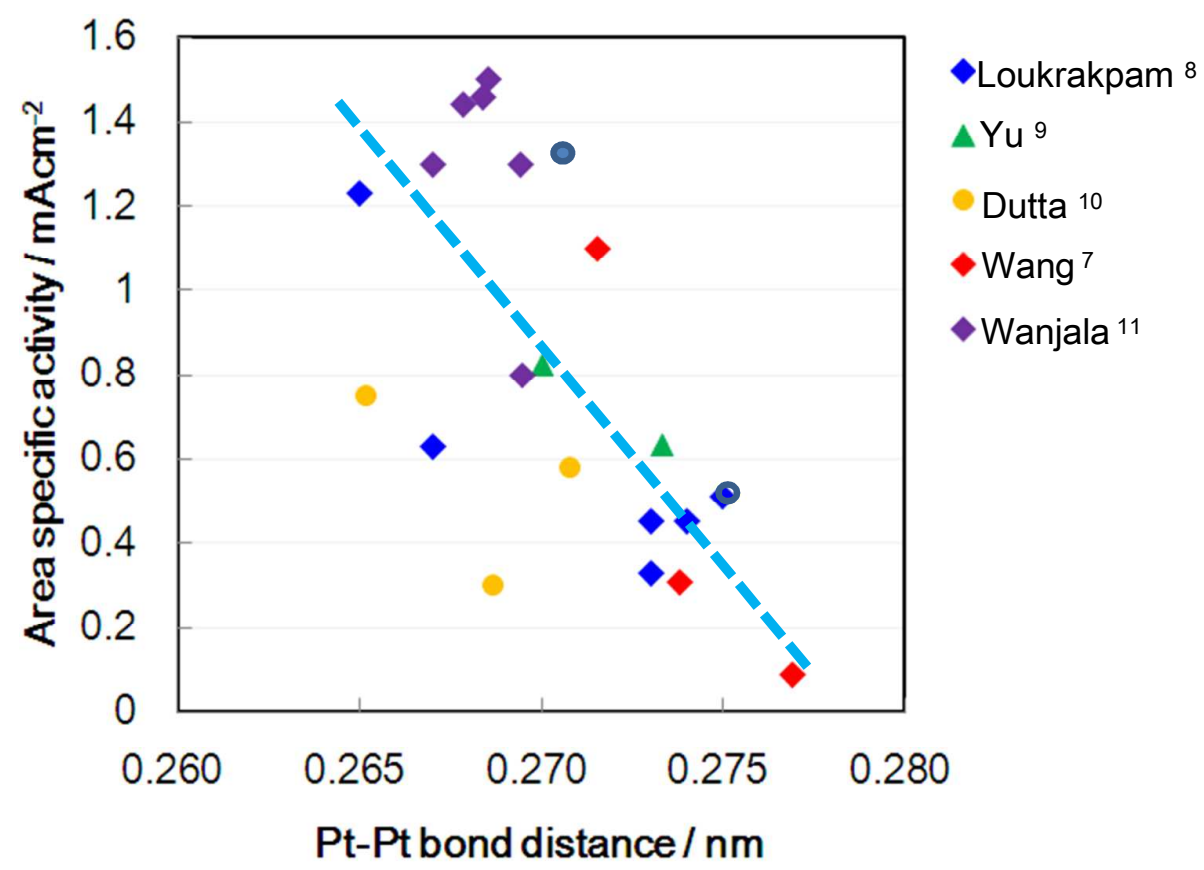

Figure S12. Correlation between Pt-Pt distances and area-specific activities of Pt alloy electrocatalysts based on data from previous reports. ${ }^{7-11}$ 
14. Atomic ratio of prepared electrocatalysts before the electrochemical testing

The atomic ratio shown in Table 1 is after electrochemical testing and the dissolution of Co or $\mathrm{Ni}$ or $\mathrm{Cu}$. The atomic ratio as prepared before electrochemical testing is shown in Table S8.

Table S8. Atomic percentages of $\mathrm{Pt} / \mathrm{C}, \mathrm{PtCo} / \mathrm{C}, \mathrm{PtCo} / \mathrm{C}-\mathrm{HT}, \mathrm{PtCu} / \mathrm{C}, \mathrm{PtCu} / \mathrm{C}-\mathrm{HT}$, and $\mathrm{PtNi} / \mathrm{C}$.

\begin{tabular}{ccccc}
\hline \hline & \multicolumn{5}{c}{${ }^{a t} \%$} \\
$\mathrm{Pt}$ & $\mathrm{Co}$ & $\mathrm{Cu}$ & $\mathrm{Ni}$ \\
\hline $\mathrm{Pt} / \mathrm{C}$ & 100 & - & - & - \\
$\mathrm{PtCo} / \mathrm{C}$ & 66 & 34 & - & - \\
$\mathrm{PtCo} / \mathrm{C}-\mathrm{HT}-600$ & 66 & 34 & - & - \\
$\mathrm{PtCo} / \mathrm{C}-\mathrm{HT}-700$ & 66 & 34 & - & - \\
$\mathrm{PtCo} / \mathrm{C}-\mathrm{HT}-800$ & 66 & 34 & - & - \\
$\mathrm{PtCo} / \mathrm{C}-\mathrm{HT}-600 \mathrm{~h}$ & 61 & 39 & - & - \\
$\mathrm{PtCu} / \mathrm{C}$ & 70 & - & 30 & - \\
$\mathrm{PtCu} / \mathrm{C}-\mathrm{HT}-600$ & 70 & - & 30 & - \\
$\mathrm{PtNi} / \mathrm{C}$ & 71 & - & - & 29 \\
\hline \hline
\end{tabular}

\section{References}

${ }^{1}$ Cook, J. J. W.; Sayers, D. E., Criteria for Automatic X-Ray Absorption Fine Structure Background Removal. J. Appl. Phys. 1981, 52, 5024-5031.

2 McMaster, W.H.; Grande, N. K-D.; Mallett, J.H.; Hubbell, J. H., Compilation of X-Ray Cross Sections. Lawrence Radiation Laboratory Report UCRL-50174 1969.

${ }^{3}$ Rehr, J. J.; Albers, R. C., Theoretical Approaches to X-Ray Absorption Fine Structure. Rev. Mod. Phys. 2000, 72, 621-654.

${ }^{4}$ Teo, B. K.; Antonio, M. R.; Averill, B. A., Molybdenum K-Edge Extended X-Ray Absorption Fine Structure Studies of Synthetic Molybdenum-Iron-Sulfur Clusters Containing the $\mathrm{MoS}_{4}$ Unit: Development of a Fine Adjustment Technique Based on Models. J. Am.Chem. Soc. 1983, 105, 37513762.

${ }^{5} \mathrm{Li}$, W.; Lane, A. M., Resolving the HUPD and HOPD by DEMS to Determine the ECSA of Pt Electrodes in PEM Fuel Cells. Electrochem. Comm. 2011, 13), 913-916.

${ }^{6}$ Gaur, A.; Shrivastava, B. D.; Joshi, S. K., Copper K-Edge XANES of Cu(I) and Cu(II) Oxide Mixtures. J. Phys.: Conf. Ser. 2009, 190, 012084.

${ }^{7}$ Wang, D.; Xin, H. L.; Hovden, R.; Wang, H.; Yu, Y.; Muller, D. A.; DiSalvo, F. J.; Abruña, H. D., Structurally Ordered Intermetallic Platinum-Cobalt Core-Shell Nanoparticles with Enhanced Activity and Stability as Oxygen Reduction Electrocatalysts. Nat. Mater2013, 12, 81-87.

${ }^{8}$ Loukrakpam, R.; Shan, S.; Petkov, V.; Yang, L.; Luo, J.; Zhong, C.-J., Atomic Odering Enhanced Electrocatalytic Activity of Nanoalloys for Oxygen Reduction Reaction. J. Phys.Chem. C. 2013, 117, 20715-20721. 
9 Yu, Z.; Zhang, J.; Liu, Z.; Ziegelbauer, J. M.; Xin, H.; Dutta, I.; Muller, D. A.; Wagner, F. T., Comparison between Dealloyed $\mathrm{Pt}_{3} \mathrm{Co}$ and $\mathrm{Pt}_{3} \mathrm{Cu}$ Cathode Catalysts for Proton Exchange Membrane Fuel Cells. J. Phys. Chem. C 2012, 116, 19877-19885.

10 Dutta, I.; Carpenter, M. K.; Balogh, M. P.; Ziegelbauer, J. M.; Moylan, T. E.; Atwan, M. H.; Irish, N. P., Electrochemical and Structural Study of a Chemically Dealloyed PtCu Oxygen Reduction Catalyst. J.Phys. Chem. C 2010, 114, 16309-16320.

11 Wanjala, B. N.; Fang, B.; Shan, S.; Petkov, V.; Zhu, P.; Loukrakpam, R.; Chen, Y.; Luo, J.; Yin, J.; Yang, L.; Shao, M.; Zhong, C.-J., Design of Ternary Nanoalloy Catalysts: Effect of Nanoscale Alloying and Structural Perfection on Electrocatalytic Enhancement. Chem.Mater. 2012, 24,, 42834293. 